\title{
International Experience in Standards and Labeling Programs for Rice Cookers
}

\author{
Nan Zhou, and Nina Zheng \\ Environmental Energy \\ Technologies Division
}

September 2008

Prepared for and with the support of the China Sustainable Energy Program of the Energy Foundation through the Department of Energy under Contract No. DE-AC02-05CH11231. 


\section{Disclaimer}

This document was prepared as an account of work sponsored by the United States Government. While this document is believed to contain correct information, neither the United States Government nor any agency thereof, nor The Regents of the University of California, nor any of their employees, makes any warranty, express or implied, or assumes any legal responsibility for the accuracy, completeness, or usefulness of any information, apparatus, product, or process disclosed, or represents that its use would not infringe privately owned rights. Reference herein to any specific commercial product, process, or service by its trade name, trademark, manufacturer, or otherwise, does not necessarily constitute or imply its endorsement, recommendation, or favoring by the United States Government or any agency thereof, or The Regents of the University of California. The views and opinions of authors expressed herein do not necessarily state or reflect those of the United States Government or any agency thereof, or The Regents of the University of California.

Ernest Orlando Lawrence Berkeley National Laboratory is an equal opportunity employer. 


\section{Table of Contents}

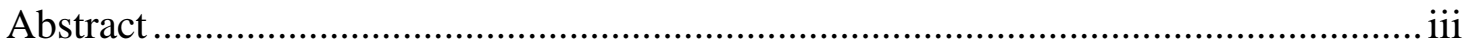

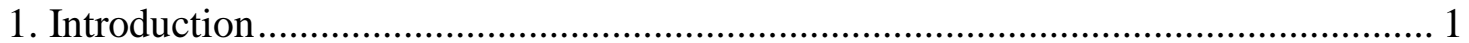

2. Overview of Rice Cooker Standards and Labeling Programs in Selected Countries . 1

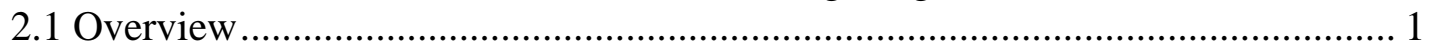

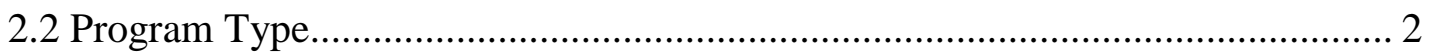

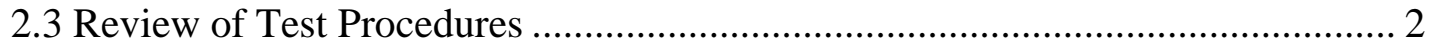

2.4 Efficiency Requirements........................................................................ 5

3. Energy Efficient Rice Cooker Technology Development in Japan .............................. 8

3.1 Historical Trend and Current Status of Rice Cooker in Japan.............................. 8

3.1.1 Trend of Domestic Shipment of Electric Rice Cookers................................. 9

3.1.2 Major Domestic Manufacturers and Retailers of Electric Rice Cookers in

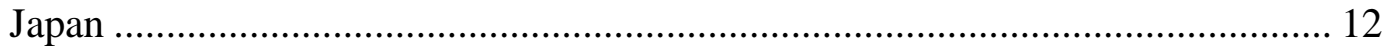

3.1.3 Consumers' Preference for Selection of Electric Rice Cookers ................... 13

3.2 Energy Saving of Electric Rice Cookers to date............................................... 13

3.2.1 Energy Saving in Warm Mode .................................................................. 13

3.2.2 Energy Saving in Standby Mode .............................................................. 14

3.2.3 Transition from Heater Type Electric Rice Cookers to IH Type.................. 15

3.2.4 Future Tasks and Issues on Energy Saving in Electric Rice Cookers ......... 15

3.3 Energy Saving Label.................................................................................. 16

3.4 Energy Efficient Rice Cooker Database …………………………………...... 17

3.5 Energy Saving Technologies ....................................................................... 22

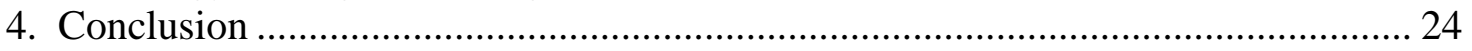

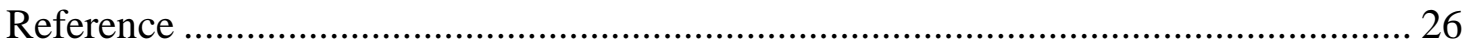




\title{
International Experience in Standards and Labeling Programs for Rice Cookers
}

\author{
Nan Zhou, and Nina Zheng
}

\section{Environmental Energy Technologies Division}

Prepared for and with the support of the China Sustainable Energy Program of the Energy Foundation through the Department of Energy under contract No. DE-AC02-05CH1123

\begin{abstract}
China has had an active program on energy efficiency standards for household appliances since the mid-1990s. Rice cooker is among the first to be subject to such mandatory regulation, since it is one of the most prevalent electric appliances in Chinese households. Since first introduced in 1989, the minimum energy efficiency standard for rice cookers has not been revised. Therefore, the potential for energy saving is considerable. Initial analysis from CNIS indicates that potential carbon savings is likely to reach 7.6 million tons of $\mathrm{CO} 2$ by the 10th year of the standard implementation.

Since September 2007, CNIS has been working with various groups to develop the new standard for rice cookers. With The Energy Foundation's support, LBNL has assisted CNIS in the revision of the minimum energy efficiency standard for rice cookers that is expected to be effective in 2009. Specifically, work has been in the following areas: assistance in developing consumer survey on usage pattern of rice cookers, review of international standards, review of international test procedures, comparison of the international standards and test procedures, and assessment of technical options of reducing energy use.

This report particularly summarizes the findings of reviewing international standards and technical options of reducing energy consumption. The report consists of an overview of rice cooker standards and labeling programs and testing procedures in Hong Kong, South Korea, Japan and Thailand, and Japan's case study in developing energy efficiency rice cooker technologies and rice cooker efficiency programs.

The results from the analysis can be summarized as the follows:

Hong Kong has a Voluntary Energy Efficiency Labeling scheme for electric rice cookers initiated in 2001, with revision implemented in 2007; South Korea has both MEPS and Mandatory Energy Efficiency Label targeting the same category of rice cookers as Hong Kong; Thailand's voluntary endorsement labeling program is similar to Hong Kong in
\end{abstract}


program design but has 5 efficiency grades; Japan's program is distinct in its adoption of the "Top Runner" approach, in which, the future efficiency standards is set based on the efficiency levels of the most efficient product in the current domestic market. Although the standards are voluntary, penalties can still be evoked if the average efficiency target is not met.

Both Hong Kong and South Korea's tests involve pouring water into the inner pot equal to $80 \%$ of its rated volume; however, white rice is used as a load for its tests in Hong Kong whereas no rice is used for tests in South Korea. In Japan's case, water level specified by the manufactures is used and milled rice is used as a load only partially in the tests. Moreover, Japan does not conduct heat efficiency test but its energy consumption measurements tests are much more complex, with 4 different tests are conducted to determine the annual average energy consumption.

Hong Kong and Thailand both set Minimum Allowable Heat Efficiency for different rated wattages. The energy efficiency requirements are identical except that the minimum heat efficiency in Thailand is 1 percentage point higher for all rated power categories. In South Korea, MEPS and label's energy efficiency grades are determined by the rice cooker's Rated Energy Efficiency for induction, non-induction, pressure, nonpressure rice cookers. Japan's target standard values are set for electromagnetic induction heating products and non-electromagnetic induction heating products by different size of rice cookers. Specific formulas are used by type and size depending on the mass of water evaporation of the rice cookers.

Japan has been the leading country in technology development of various types of rice cookers, and developed concrete energy efficiency standards for rice cookers. However, as consumers in Japan emphasize the deliciousness of cooked rice over other factors, many types of models were developed to improve the taste of cooked rice. Nonetheless, the efficiency of electromagnetic induction heating $(\mathrm{IH})$ rice cookers in warm mode has improved approximately 12 percent from 1993 to 2004 due to the "low temperature warming method" developed by manufacturers.

The Energy Conservation Center of Japan (IEEJ) releases energy saving products database on the web regularly, on which the energy saving performance of each product is listed and ranked.

Energy saving in rice cookers mostly rest with insulation of the pot. Technology developed to improve the energy efficiency of the rice cookers includes providing vacuum layers on both side of the pot, using copper-plated materials, and double stainless layer lid that can be heated and steam can run in between the two layers to speed the heating process. 


\section{Introduction}

China has had an active program on energy efficiency standards for household appliances since the mid-1990s. Rice cooker is among the first to be subject to such mandatory regulation, since it is one of the most prevalent electric appliances in Chinese households. According to China National Institute if Standardization (CNIS)'s estimates, outputs of rice cookers have reached almost 49 million units per year, with an annual growth rate of $18 \%$. Annual energy use per unit is estimated to be $138 \mathrm{kWh}$ (daily use assumed), almost approaching that of television sets.

Since first introduced in 1989, the minimum energy efficiency standard for rice cookers has not been revised. Therefore, the potential for energy saving is considerable. Initial analysis from CNIS indicates that potential carbon savings is likely to reach 7.6 million tons of $\mathrm{CO} 2$ by the $10^{\text {th }}$ year of the standard implementation.

This project builds on CSEP's current effort of assisting China in the development of energy efficiency standards and labels, which have proven to be very effective in reducing energy use and associated emissions of greenhouse gases (GHG). In this project, LBNL's role is to assist CNIS in the revision of the minimum energy efficiency standard for rice cookers that is expected to be effective in 2009. Specifically, work has been in the following areas: review of international standards, review of international test procedures, and assessment of technical options of reducing energy use.

This report summarizes the results of the findings that consists of an overview of rice cooker standards and labeling programs and testing procedures in Hong Kong, South Korea, Japan and Thailand, and Japan's case study in developing energy efficiency rice cooker technologies and rice cooker efficiency programs.

\section{Overview of Rice Cooker Standards and Labeling Programs in Selected Countries}

\subsection{Overview}

In addition to China, there are currently four other countries with a minimum standards and/or a labeling program for electric rice cookers. These include Hong Kong, South Korea, Thailand and Japan, with Vietnam still considering the adoption of a labeling program. Hong Kong's Voluntary Energy Efficiency Labeling Scheme for Electric RiceCookers was initiated on December 28, 2001, with revisions implemented in January 2007. This was followed by South Korea's mandatory minimum energy performance standards (MEPS) and labeling program, which went into effect on January 1, 2004. Thailand also introduced a voluntary labeling program for rice cookers on July 26, 2004. Japan then introduced its "Top Runner" standards and voluntary labeling program for rice cookers in 2006. 


\subsection{Program Type}

Hong Kong's voluntary electric rice cookers standards and labeling program operates as a "endorsement" program, where appliances that meet specified energy efficiency performance requirements are recognized by an endorsement label. This program applies to electrically operated rice-cookers with maximum cooking capacity of 3.6 liters and rated power consumption of $2 \mathrm{~kW}$. Interestingly, Hong Kong's heat efficiency MEPS are higher than China's MEPS.

While South Korea's program targets the same category of rice cookers as Hong Kong, it uses minimum energy performance standards and a mandatory energy efficiency label. Under this program, manufacturers can only sell rice cookers that meet the MEPS and are marked by a label which indicates the energy efficiency and consumption of the cooker. The label also indicates the cooker's energy efficiency grade, which range from 1 being the most efficient to 5 being the least efficient.

Thailand's voluntary endorsement labeling program is similar to Hong Kong in program design, but the "No. 5" Energy Label used is similar to South Korea's mandatory comparative label because it uses 5 efficiency classes. In particular, Class 5 is used to designate the most efficient appliances while Class 3 designates the appliances that meet the minimum heat efficiency requirements. However, Thailand's comparative label has recognized only 15 models of rice cookers with 1.8 L capacity.

Japan's program is distinct in its adoption of the "Top Runner" approach for its appliance energy efficiency standards as the basis for its voluntary endorsement labeling program. Similar to the Hong Kong program, an endorsement label is granted to rice cookers able to meet a certain standard, the top-runner standard in this case. In turn, the top-runner approach sets future efficiency standards based on the efficiency levels of the most efficient product in the current domestic market. The goal of this approach is continuous improvement over time by providing incentives for manufacturers to develop more energy efficient appliances. At the same time, manufacturers and importers must ensure the average, or sales weighted efficiency of their entire appliances fleet, meet the top-runner standard by the target year. Although the Top Runner standards are voluntary because they do not have a minimum level, penalties can still be evoked if the average efficiency target is not met. In terms of target scope, the Top Runner program is also unique in that it does not have a maximum cooking capacity. Rather, it only excludes electric rice cookers with a maximum capacity below $0.54 \mathrm{~L}$ and cookers for industrial use. This program also has a more complex classification scheme, with 2 levels of division for method of cooking and maximum capacity size.

\subsection{Review of Test Procedures}

\section{Test Conditions}


Hong Kong's testing requirements for measuring heat efficiency are based on CCEC/T11-2006 "Technical Specifications for Energy Conservation Production Certification for Household Automatic Rice Cooker."

The main specified test conditions for testing heat efficiency and energy consumption include:

a) Relative humidity in the range of $45 \%$ to $75 \%$

b) Atmospheric pressure within the range of 86 to $106 \mathrm{kPa}$

c) Ambient temperature of $20^{\circ} \mathrm{C} \pm 2{ }^{\circ} \mathrm{C}$ where the test room will not be affected by wind and heat radiation

e) The electric rice-cooker must not be operating for more than 6 hours prior to the heat efficiency test OR the temperature difference among the inner pot, heating element, outer pot and the ambient temperature must be within $5 \mathrm{~K}$.

Similarly, South Korea's testing requirements includes the same ambient temperature and relative humidity conditions. However, South Korea differs in that it specifies the cooking water must be distilled water or service water that has been settled for more than 2 hours. Additionally, its tests are conducted with different classifications for rice cookers according to the heating method and pressure type. Specifically, separate rice cooker classifications exist for plate vs. induction heating and pressure vs. non-pressure type.

While there are no details on the initial test conditions or testing procedures for Thailand's rice cooker labeling program, it is likely to similar to Hong Kong and Japan's procedures as it uses Hong Kong and Japans' test standards as references.

Japan, on the other hand, has very different initial conditions for its testing requirements. First, it has a higher ambient temperature of $23^{\circ} \mathrm{C} \pm 2{ }^{\circ} \mathrm{C}$ and also specifies the same temperature for the cooking water. Second, it requires that the cooking rice be washed three times within 20 seconds each time prior to testing. Like Korea, Japan also conducts separate tests for rice cookers with the plate vs. induction heating method. It also goes a further step to classify the rice cookers by 4 ranges of maximum capacity sizes, including $\geq$ 0.54 to $<0.99 \mathrm{~L}, \geq 0.99$ to $<1.44 \mathrm{~L}, \geq 1.44$ to $<1.80 \mathrm{~L}$ and $1.80 \mathrm{~L}$ and over.

\section{Efficiency Measurement}

Both Hong Kong and South Korea's measurement tests involve pouring water into the inner pot equal to $80 \%$ of its rated volume. A major difference between the two countries' testing procedure is that Hong Kong uses white rice as a load for its tests while South Korea does not seem to have a load. Japan's testing procedures also differs because it uses the water level specified by the manufacturer and uses milled rice as a load for only some parts of the procedure. More importantly, Japan does not conduct the heat efficiency test but its energy consumption measurement tests are much more complex, with 4 different tests are conducted to determine the annual average energy consumption. 
The rice-cooker is tested at the rated voltage of $220 \pm 2.2$ volts in both Hong Kong and South Korea but at different frequencies of $50 \pm 0.5 \mathrm{~Hz}$ and $60 \pm 0.6 \mathrm{~Hz}$, respectively. Japan, on the other hand, tests rice cookers at $100 \pm 1$ volts and frequencies of $50 \pm 0.1$ $\mathrm{Hz}$ or $60 \pm 0.1 \mathrm{~Hz}$.

The measurements methods of Hong Kong, South Korea and Japan also have notable differences. For Hong Kong, energy consumption (E) and maximum temperature (T2) are recorded when the temperature of water is raised up to $95^{\circ} \mathrm{C}$ and the cooker is disconnected from its power supply.

Hong Kong's heat efficiency $(\eta)$ at ambient temperature is calculated using the following equation :

$\eta=\frac{1.16 \mathrm{G} 1(\mathrm{~T} 2-\mathrm{T} 1) \times 100 \%}{\mathrm{E}}+\frac{\mathrm{CG} 2(\mathrm{~T} 2-\mathrm{T} 1) \times 100 \%}{3.6 \mathrm{E}}$

Where $\eta$-- heat efficiency, $\%$, to the nearest $0.1 \%$.

G1 - mass of water before test, $\mathrm{kg}$;

$\mathrm{T} 1$-- temperature of water before test, ${ }^{\circ} \mathrm{C}$;

$\mathrm{T} 2$-- maximum temperature of water after the test, ${ }^{\circ} \mathrm{C}$;

$\mathrm{C}$-- specific heat capacity of the material of the inner pot, $\mathrm{kJ} / \mathrm{kg} \cdot \mathrm{K}$

$\mathrm{G} 2$ - mass of the inner pot, $\mathrm{kg}$;

E - energy consumption, Wh.

$3.6-1 / 1000 \times 3600$ seconds/hr

For South Korea, energy consumption is measured 4 minutes after cooking mode started. The top cover is then closed and the maximum temperature measured. The test is performed 4 times with the same procedure with the average data taken as the final measurement.

Cooking Efficiency $(\%)=\frac{\text { Output }}{\text { Input }}=\frac{\Delta T \times\left[Q+\left(W g_{1} \times C P_{1}\right)+\left(W g_{2} \times C P_{2}\right)\right] \times 100}{0.24 \times E c \times 3600}$

Where, Q : Water weight (g)

$\mathrm{Wg}_{1}$ : Inner pan weight (g), Aluminum

$\mathrm{Wg}_{2}$ : Inner pan weight $(\mathrm{g})$, Stainless Steel

$\mathrm{CP}_{1}: 0.22 \mathrm{~kJ} / \mathrm{kg} \mathrm{K}$, specific heat of Aluminum

$\mathrm{CP}_{2}: 0.12 \mathrm{~kJ} / \mathrm{kg} \mathrm{K}$, specific heat of Stainless Steel

$\mathrm{T}_{1}$ : an initial water temperature in an inner pan,

$\mathrm{T}_{2}$ : a final water temperature in an inner pan,

Ec : Electric power consumption, (Wh)

3600 : second, 1 hour

0.24: 240 seconds/100, time of energy input for cooking

For Japan, 4 different tests representing the cooking, rice warming, timer, and standby modes are conducted. For the cooking mode, the energy from the start to completion of 
cooking is measured and averaged over 3 tests. The rice warming mode measures the energy consumed while an electric rice cooker warms the rice for 1 hour immediately following the cooking mode. For both the timer and standby mode testing, energy consumption is measured for 1 hour in each respective mode without rice in the cooker. The annual average energy efficiency is then calculated based on each mode's test results and proportion of annual use, as illustrated by the formula below.

The values for NA, HB, HC, and HD are shown in Table 1.

$\mathrm{E}=\{(\mathrm{A} \times \mathrm{NA})+(\mathrm{B} \times \mathrm{HB})+(\mathrm{C} \times \mathrm{HC})+(\mathrm{D} \times \mathrm{HD})\} / 1000$

The variables (E, A, NA, B, HB, C, HC, D and HD) in the equation express the following values:

E: Energy consumption [kWh/year]

A: Energy in cooking mode per use [Wh/use]

NA: Number of uses per year [use/year]

B: Energy to keep rice warm per hour [Wh/h]

HB: Hours of keeping rice warm per year [h/year]

$\mathrm{C}$ : Energy in timer mode per hour [Wh/h]

$\mathrm{H}_{\mathrm{C}}$ : Hours in timer mode per year [h/year]

D: Energy in standby mode per hour [Wh/h]

HD: Hours in standby mode per year [h/year]

Table 1 Coefficients of Japan's Formula for Energy Efficiency Calculation

\begin{tabular}{|l|c|c|c|c|}
\hline $\begin{array}{l}\text { Maximum Rice } \\
\text { Cooking Capacity } \\
(\mathrm{L})\end{array}$ & NA & HB & $\mathbf{H}_{\mathbf{C}}$ & HD \\
\hline$\geq 0.54$ to $<0.99 \mathrm{~L}$ & 290 & 920 & 750 & 2,760 \\
\hline$\geq 0.99$ to $<1.44 \mathrm{~L}$ & 340 & 1540 & 1190 & 2,990 \\
\hline$\geq 1.44$ to $<1.80 \mathrm{~L}$ & 390 & 2180 & 1880 & 1210 \\
\hline$\geq 1.80$ L and over & 350 & 2420 & 1000 & 2,150 \\
\hline
\end{tabular}

Source: ERCCSS, 2005

\subsection{Efficiency Requirements}

Hong Kong's voluntary labeling efficiency standards are based on the minimum allowable heat efficiency standards. 
Table 2: Hong Kong MEPS Levels

\begin{tabular}{|c|c|}
\hline Rated Wattage (P) W & Minimum Allowable Heat Efficiency $(\eta) \%$ \\
\hline$P \leq 400 W$ & 84 \\
\hline $400 \mathrm{~W}<\mathrm{P} \leq 600 \mathrm{~W}$ & 85 \\
\hline $600 \mathrm{~W}<\mathrm{P} \leq 800 \mathrm{~W}$ & 86 \\
\hline $800 W<P \leq 1000 W$ & 87 \\
\hline $1000 \mathrm{~W}<\mathrm{P} \leq 2000 \mathrm{~W}$ & 88 \\
\hline
\end{tabular}

Source: http://www.emsd.gov.hk/emsd/eng/pee/eels_sch_doc.shtml

Thailand's labeling efficiency requirements are very similar to Hong Kong's requirements, except that its minimum heat efficiency percentages are 1 percentage point higher for all rated power categories.

Table 3: Thailand MEPS Levels

\begin{tabular}{|c|c|}
\hline Rated Power P, (watt) & Minimum Heat Efficiency, \% \\
\hline $\mathrm{P} \leq 400$ & 85 \\
\hline $400<\mathrm{P} \leq 600$ & 86 \\
\hline $600<\mathrm{P} \leq 800$ & 87 \\
\hline $800<\mathrm{P} \leq 1000$ & 88 \\
\hline $1000<\mathrm{P} \leq 2000$ & 89 \\
\hline
\end{tabular}

South Korea's MEPS and label's energy efficiency grades are determined by the rice cooker's classification, as seen in the four tables below (Table 4 to Table 7), where $\mathrm{R}($ Energy Efficiency Level Index) = Rated cooking efficiency $(\%)$

Table 4: South Korea MEPS Levels for Plate Heating in Non-Pressure Rice Cookers

\begin{tabular}{|c|c|}
\hline Rated Energy Efficiency $(\mathrm{R})$ & Level \\
\hline $94 \% \leq \mathrm{R}$ & 1 \\
\hline $90 \% \leq \mathrm{R}<94 \%$ & 2 \\
\hline $86 \% \leq \mathrm{R}<90 \%$ & 3 \\
\hline $82 \% \leq \mathrm{R}<86 \%$ & 4 \\
\hline $78 \% \leq \mathrm{R}<82 \%$ & 5 \\
\hline
\end{tabular}

Table 5: South Korea MEPS Levels for Plate Heating in Pressure Rice Cookers 


\begin{tabular}{|c|c|c|}
\hline $\begin{array}{c}\text { Rated Energy Efficiency } \\
(\mathrm{R})\end{array}$ & $\begin{array}{c}\text { Standby power } \\
\text { (No load mode) }\end{array}$ & Level \\
\hline $90 \% \leq \mathrm{R}$ & $\leq 1.0 \mathrm{~W}$ & 1 \\
\hline $90 \% \leq \mathrm{R}$ & N/A & 2 \\
\hline $86 \% \leq \mathrm{R}<90 \%$ & N/A & 3 \\
\hline $82 \% \leq \mathrm{R}<86 \%$ & N/A & 4 \\
\hline $78 \% \leq \mathrm{R}<82 \%$ & N/A & 5 \\
\hline
\end{tabular}

Table 6: South Korea MEPS Levels for Induction Heating in Non-Pressure Rice Cookers

\begin{tabular}{|c|c|c|}
\hline $\begin{array}{c}\text { Rated Energy Efficiency } \\
(\mathrm{R})\end{array}$ & $\begin{array}{c}\text { Standby power } \\
\text { (No load mode) }\end{array}$ & Level \\
\hline $92 \% \leq \mathrm{R}$ & $\leq 1.0 \mathrm{~W}$ & 1 \\
\hline $92 \% \leq \mathrm{R}$ & N/A & 2 \\
\hline $88 \% \leq \mathrm{R}<92 \%$ & N/A & 3 \\
\hline $84 \% \leq \mathrm{R}<88 \%$ & N/A & 4 \\
\hline $80 \% \leq \mathrm{R}<84 \%$ & N/A & 5 \\
\hline
\end{tabular}

Table 7: South Korea MEPS Levels for Induction Heating in Pressure Rice Cookers

\begin{tabular}{|c|c|c|}
\hline $\begin{array}{c}\text { Rated Energy Efficiency } \\
(\mathrm{R})\end{array}$ & $\begin{array}{c}\text { Standby power } \\
\text { (No load mode) }\end{array}$ & Level \\
\hline $90 \% \leq \mathrm{R}$ & $\leq 3.0 \mathrm{~W}$ & 1 \\
\hline $90 \% \leq \mathrm{R}$ & N/A & 2 \\
\hline $86 \% \leq \mathrm{R}<90 \%$ & N/A & 3 \\
\hline $82 \% \leq \mathrm{R}<86 \%$ & N/A & 4 \\
\hline $78 \% \leq \mathrm{R}<82 \%$ & N/A & 5 \\
\hline
\end{tabular}

Japan's target standard values are set for electromagnetic induction heating products and non-electromagnetic induction heating products by different size of rice cookers. Specific formulas are used by type and size depending on the mass of water evaporation of the rice cookers (Table 8).

Table 8: Japan's Top Runner Standard Targets 


\begin{tabular}{|c|c|c|c|}
\hline \multicolumn{3}{|c|}{ Category } & \multirow{2}{*}{$\begin{array}{l}\text { Calculation equation for standard } \\
\text { energy consumption efficiency }\end{array}$} \\
\hline Heating method & Maximum rice cooking capacity & Calagary name & \\
\hline \multirow{4}{*}{$\begin{array}{l}\text { Electromagnetic induction } \\
\text { heating products }\end{array}$} & 0.54 liters or more, and less than 0.99 liters & A & $E_{K}=0.209 M+48.5$ \\
\hline & 0.99 liters or more, and less than 1.44 liters & $\mathrm{B}$ & $E_{K}=0.244 \mathrm{M}+83.2$ \\
\hline & 1.44 liters or more, and less than 1.80 liters & $\mathrm{C}$ & $E_{K}=0.280 M+132$ \\
\hline & 1.80 liters or more & $\mathrm{D}$ & $E_{K}=0.252 M+132$ \\
\hline \multirow{4}{*}{$\begin{array}{l}\text { Non-electromagnetic induction } \\
\text { heating products }\end{array}$} & 0.54 liters or more, and less than 0.99 liters & $E$ & $E_{\kappa}=0.209 M+36.7$ \\
\hline & 0.99 liters or more, and less than 1.44 liters & $\mathrm{F}$ & $E_{K}=0.244 \mathrm{M}+75.6$ \\
\hline & 1.44 liters or more, and less than 1.80 liters & $\mathrm{G}$ & $E_{K}=0.280 M+99.0$ \\
\hline & 1.80 ititers or more & $\mathrm{H}$ & $E_{K}=0.252 M+122$ \\
\hline
\end{tabular}

Remarks

1. The maximum rice cooking capacity shall be determined by multiplying the volume of the measuring cup specified by the manufacturer (liter) by the maximum number of cups that the product is designed for.

2. EK and $M$ represent the following numerical values.

Ek: Standard energy consumption efficiency ( $k W h$ per year)

M: Mass of evaporated water (This is the mass of water expelled from the rice cooker when electric power consumption is measured for each rice cooking operation, and is the mean value of the mass of evaporated water obtained at every measurement of electric power consumption during cooking rice. The mass of water expelled from the rice cooker is calculated by subtracting the measured weight of the rice cooker within 1 minute after completion of cooking prior to opening the lid from the weight of the rice cooker containing water and rice prior to the start of cooking. It is expressed in grams and rounded off to 1 decimal place.)

Source: http://www.eccj.or.jp/top_runner/index_contents_e.html, (ECCJ, 2008a)

\section{Energy Efficient Rice Cooker Technology Development in Ja- pan}

Rice is the predominant food in Japan, thus the rice cooker is one of the most important home appliances. Japan has been the leading country in technology development of various types of rice cookers, and developed concrete energy efficiency standards for deferent size and type of rice cookers. In addition, Japan has the most information available on the energy efficiency of rice cookers; this section intends to describe Japan's experience in developing rice cooker technologies. Note that the information provided in this section is largely based on Final Report on the Top Runner Target Rice Cooker Standards produced by the Advisory Committee on Energy and Natural Resources of Japan for its standard setting for rice cookers (ERCCSS, 2005)

\subsection{Historical Trend and Current Status of Rice Cooker in Japan}

Rice cookers first appeared in Japan in 1955, and in 1972, a rice cooker combined with an electronic jar ${ }^{1}$ to keep warm was developed (also called a mechanical rice cooker). Further, in 1979, manufacturers released electronic jar rice cookers with microcomputers, with which there is no more need to soak rice after washing, and the heating level became adjustable according to the volume of rice. Later, rice cookers with memory timers that

\footnotetext{
1 An appliance to keep the food warm
} 
can easily set a fixed time emerged in the market. In addition, in response to users' need for "greater taste of rice", rice cookers with a mechanism to control heat was then developed. In 1988, the first IH rice cooker was released. Instead of the conventional heating system, this type of cooker employed Electromagnetic Induction Heating (IH) system which generates great heating power. Because rice is such an important factor in Japanese food culture, more technologies developed to improve the taste of the cooked rice.

Table 9 shows the control method and heating system of different types of rice cookers.

Table 9 Control Method and Heating System of Different Types of the Rice Cooker.

\begin{tabular}{|l|l|l|l|}
\hline Method & $\begin{array}{l}\text { Mechanical Rice Cookers } \\
\text { The rice cooker is powered by a } \\
\text { steady electric current. A built-in } \\
\text { thermal sensor switch located un- } \\
\text { der the rice cooker pot detects } \\
\text { when the water runs out, and a } \\
\text { mechanical switch cuts off the elec- } \\
\text { tricity. }\end{array}$ & $\begin{array}{l}\text { Microcomputer Rice } \\
\text { Cookers }\end{array}$ & $\begin{array}{l}\text { IH Rice Cookers } \\
\text { puter receives information from semicon- } \\
\text { ductor thermal sensors located under the pot } \\
\text { and inside the lid of a rice cooker and uses } \\
\text { this information to control the volume of } \\
\text { electric current. }\end{array}$ \\
\hline $\begin{array}{l}\text { Heating } \\
\text { System }\end{array}$ & $\begin{array}{l}\text { Direct heating system } \\
\text { The rice cooker's pot is heated by } \\
\text { thermal conduction from the heater. }\end{array}$ & & $\begin{array}{l}\text { Electromagnetic In- } \\
\text { duction Heating } \\
\text { System Coils gen- } \\
\text { erate an eddy cur- } \\
\text { rent in the rice } \\
\text { cooker pot material, } \\
\text { and the pot heats up } \\
\text { due to electric re- } \\
\text { sistance. }\end{array}$ \\
\hline
\end{tabular}

\subsubsection{Trend of Domestic Shipment of Electric Rice Cookers}

The domestic shipments of electric rice cookers have been steady since 1990 . Total shipments in 2003 were 6.271 million units and the overseas production of electric rice cookers exceeded the domestic production. Many of the imported products are manufactured by Japanese companies overseas and sold in Japan as imports. Since IH electric rice cookers were introduced in 1988, the share has been increasing steadily, currently accounting for more than half all rice cookers shipped domestically (Table 10 and Figure $1)$.

Table 10 Domestic Shipments of IH Electric Rice Cookers and Non-IH Electric Rice Cookers

\begin{tabular}{|l|l|l|l|}
\hline Fiscal Year & IH Type & Non-IH Type & Total \\
\hline
\end{tabular}




\begin{tabular}{|l|l|l|l|}
\hline 1994 & 2,007 & 4,615 & 6,622 \\
\hline 1995 & 2,365 & 3,890 & 6,256 \\
\hline 1996 & 2,831 & 4,020 & 6,851 \\
\hline 1997 & 2,915 & 3,516 & 6,431 \\
\hline 1998 & 2,959 & 3,191 & 6,150 \\
\hline 1999 & 3,056 & 3,049 & 6,104 \\
\hline 2000 & 3,201 & 2,990 & 6,191 \\
\hline 2001 & 3,184 & 2,918 & 6,102 \\
\hline 2002 & 3,297 & 2,948 & 6,244 \\
\hline 2003 & 3,424 & 2,847 & 6,271 \\
\hline
\end{tabular}

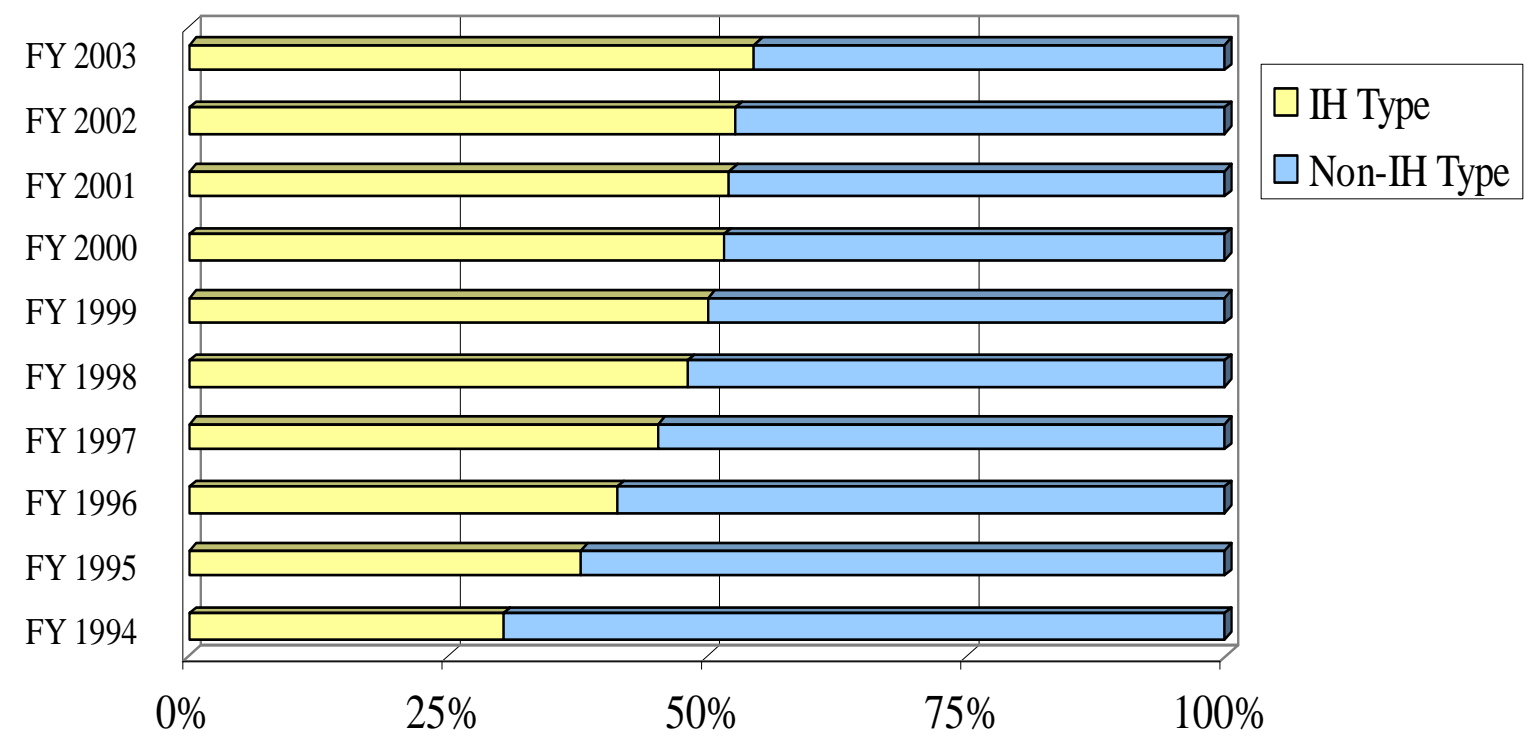

Source: Japan Electrical Manufacturers’ Association

\section{Figure 1 Share of Domestic Shipment Electric Rice Cooker by Type}

Table 11 shows domestic shipments of electric rice cookers by cooking capacity. The ratio of domestic shipments corresponding to each capacity type is presented in Figure 2. Domestic shipments of smaller rice cookers $(<0.99 \mathrm{~L})$ have been steady over time, whereas medium sized rice cookers $(\geq 0.99$ to $<1.8 \mathrm{~L})$ have increased their share and now account for nearly 60 percent of the total domestic shipments of electric rice cookers. Domestic sales are declining in recent years is also a result of more products were manufactured by oversea Japanese companies and imported back to Japan as imports.

Table 11 Domestic Shipments of Electric Rice Cookers by Cooking Capacity

\begin{tabular}{|l|c|c|c|c|}
\hline $\begin{array}{l}\text { Fiscal } \\
\text { Year }\end{array}$ & $<0.99 \mathrm{~L}$ & $\geq 0.99$ to $<1.8 \mathrm{~L}$ & $1.8 \mathrm{~L}$ and over & $\begin{array}{c}\text { Total Number of } \\
\text { Electric Rice Cookers }\end{array}$ \\
\hline 1994 & 998 & 2,940 & 2,281 & 6,219 \\
\hline
\end{tabular}




\begin{tabular}{|l|c|c|c|c|}
\hline 1995 & 1,052 & 3,001 & 2,265 & 6,318 \\
\hline 1996 & 993 & 2,957 & 2,229 & 6,179 \\
\hline 1997 & 957 & 3,121 & 2,274 & 6,352 \\
\hline 1998 & 1,009 & 3,342 & 2,271 & 6,622 \\
\hline 1999 & 998 & 3,161 & 2,097 & 6,256 \\
\hline 2000 & 1,160 & 3,421 & 2,271 & 6,851 \\
\hline 2001 & 1,132 & 3,213 & 2,086 & 6,431 \\
\hline 2002 & 1,172 & 3,109 & 1,868 & 6,150 \\
\hline 2003 & 1,162 & 3,148 & 1,794 & 6,104 \\
\hline
\end{tabular}

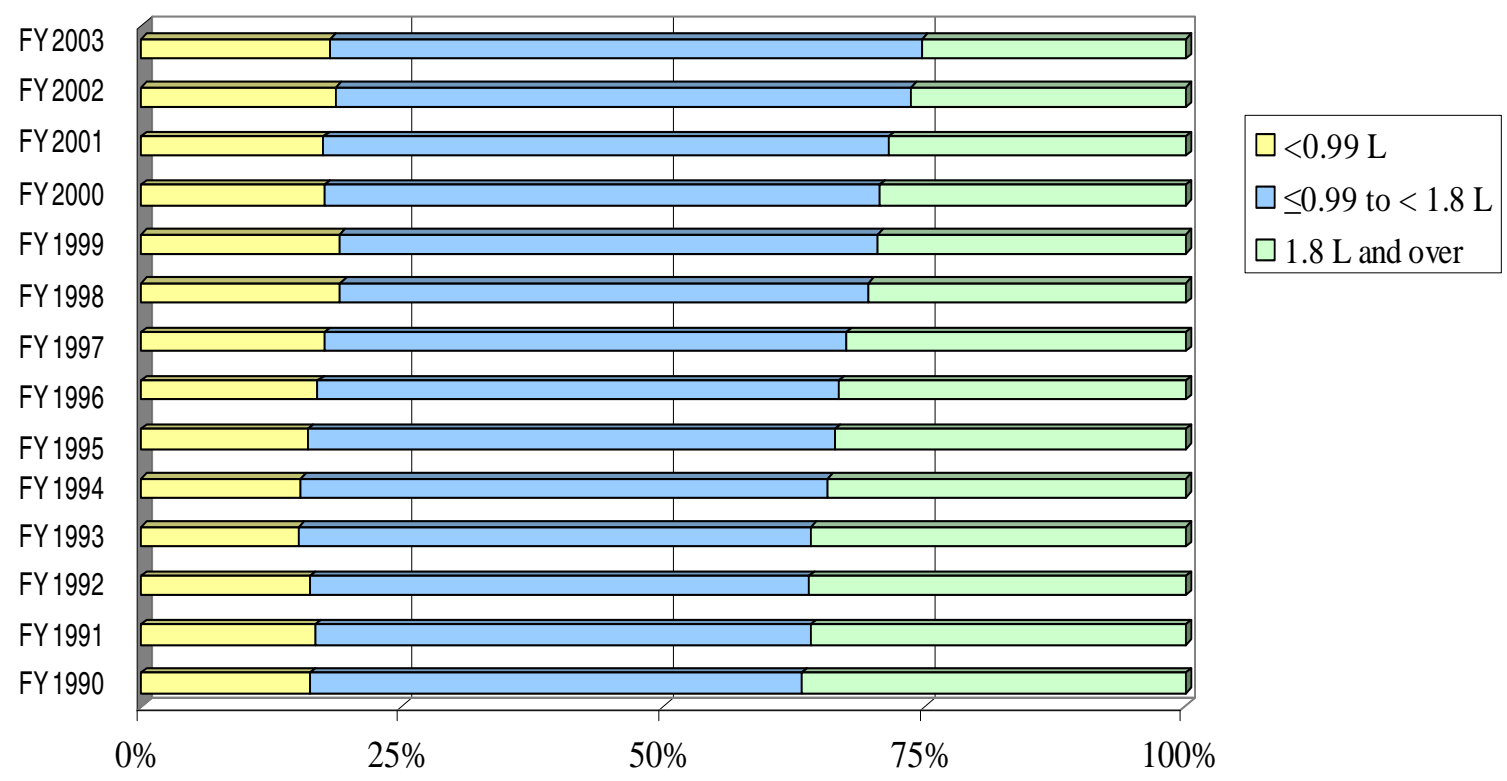

Figure 2 Share of Domestic Shipment Electric Rice Cooker by Capacity

Table 12 shows the number of domestic shipments of electric rice cookers by cooking capacity and by type, and Figure 3 shows the breakdown of electric rice cookers by capacity and by type in fiscal year 2003. In recent years, medium sized IH rice cookers $(\geq 0.99$ to $<1.8 \mathrm{~L}$ ) accounted for approximately one-third of total domestic shipments of electric rice cookers. In addition, more non-IH type of rice cookers are observed in the smaller size (< $0.99 \mathrm{~L}$ ) than in other size categories (medium and larger capacities) (Figure 4)

Table 12 Number of Domestic Shipments of Electric Rice Cookers by Cooking Capacity and by Type

\begin{tabular}{|c|c|c|c|c|c|c|c|c|c|}
\hline Fiscal & \multicolumn{4}{|c|}{ IH type } & \multicolumn{4}{|c|}{ Non-IH Type } & Total \\
\cline { 2 - 10 } & $\begin{array}{c}<0.99 \\
\mathrm{~L}\end{array}$ & $\begin{array}{c}\geq 0.99 \\
\text { to }<1.8 \\
\mathrm{~L}\end{array}$ & $\begin{array}{c}1.8 \mathrm{~L} \\
\text { and } \\
\text { over }\end{array}$ & Subtotal & & $\begin{array}{c}<0.99 \\
\mathrm{~L}\end{array}$ & $\begin{array}{c}\geq 0.99 \\
\text { to }<1.8 \\
\mathrm{~L}\end{array}$ & $\begin{array}{c}1.8 \mathrm{~L} \\
\text { and } \\
\text { over }\end{array}$ & Subtotal \\
\\
\hline 1999 & 188 & 1,800 & 1,068 & 3,056 & 974 & 1,348 & 726 & 3,048 & 6,104 \\
\hline 2000 & 179 & 1,921 & 1,102 & 3,202 & 906 & 1,374 & 710 & 2,990 & 6,192 \\
\hline
\end{tabular}




\begin{tabular}{|l|c|c|c|c|c|c|c|c|c|}
\hline 2001 & 196 & 1,938 & 1,051 & 3,185 & 870 & 1,366 & 682 & 2,918 & 6,103 \\
\hline 2002 & 184 & 2,097 & 1,016 & 3,297 & 979 & 1,341 & 628 & 2,948 & 6,245 \\
\hline 2003 & 197 & 2,241 & 986 & 3,424 & 932 & 1,322 & 593 & 2,847 & 6,271 \\
\hline
\end{tabular}


Figure 3 Share of IH and Non-IH Rice Cookers Shipped in 2003 for Each Capacity

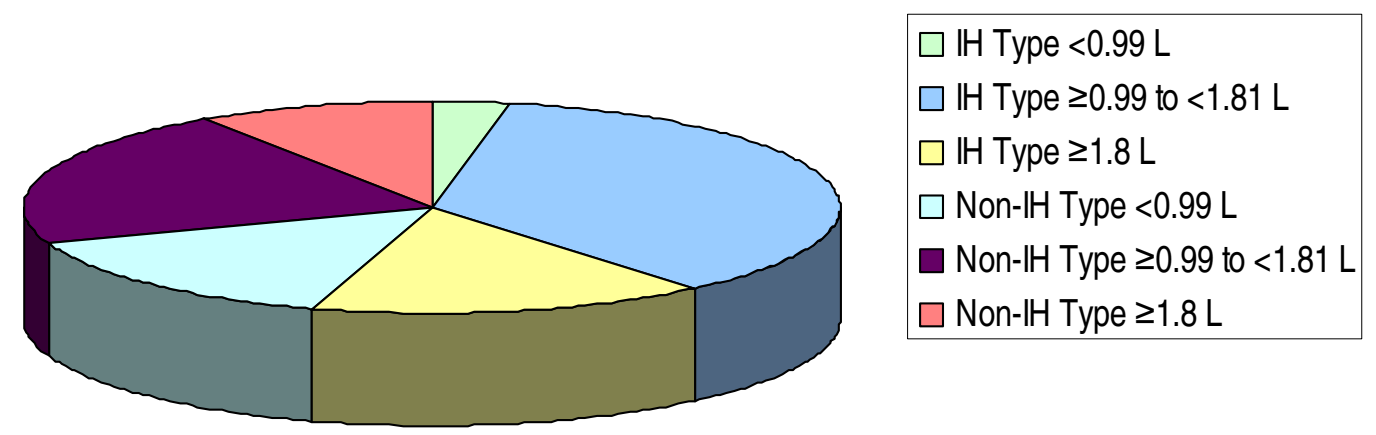

Figure 4 Share of IH and Non-IH Rice Cookers Shipped in 2003 by Capacity and by Type

\subsubsection{Major Domestic Manufacturers and Retailers of Electric Rice Cookers in Ja- pan}

The major domestic manufacturers and retailers of electric rice cookers includes: Sanyo Electric Co. Ltd., Sharp Corporation, ZOJIRUSHI CORPORATION, Tiger Corporation, Toshiba Corporation, Hitachi Home and Life Solutions Inc., Matsushita Electric Industrial Co. Ltd., Mitsubishi Electric Corporation.

The Japanese market for rice cookers is somewhat unique. Unlike other home appliances, there are not many electric rice cookers produced by overseas manufacturers. The main reason is that the Japanese prefer to eat non-glutinous rice rather than long-grain rice that is generally preferred overseas. Differences may exist in cooking requirements for these 
two kinds of rice that would lead to the predominance of domestic manufactures in the market.

\subsubsection{Consumers' Preference for Selection of Electric Rice Cookers}

Unlike many other appliances, energy efficiency in rice cookers is not a priority, and may not even be one of the most important factors when consumers choose the models. According to a manufacturer conducted survey, "What do Consumers Expect from Electric Rice Cookers", the deliciousness of cooked rice is the most important factor to consumers, followed by the price (Table 13). Based on the survey, manufacturers have put their focus on improving the taste of the rice cooked over the energy efficiency of the rice cookers. Many types of models have been developed to improve the taste of cooked rice including Steam IH type, Steam Pressure, Clay Rice Cooker, and Ultrasonic Boiling type $^{2}$. In order to improve the taste of cooked rice, manufacturers have developed their own standards in volume of heat and control methods for heating employed in electric rice cookers, to improve the relative taste of cooked rice based on their experience.

\section{Table 13 What Consumers Expect from Electric Rice Cookers at the Time of Pur- chase (percentage of total samples) ${ }^{3}$}

Deliciousness of cooked rice

Deliciousness of cooked rice in warm mode

Price

Energy efficiency

Ease of maintenance

Ease of operation

Size

Time required to cook rice

Design

Consideration for recycling

Weight

Ease of carry

\subsection{Energy Saving of Electric Rice Cookers to date}

\subsubsection{Energy Saving in Warm Mode}

Even though energy efficiency is not top priority for rice cookers in Japan, there have been efforts made to improve the efficiency over time. The manufactures found that the condition of rice in warm mode varies greatly depending on the temperature of the warm mode (Figure 5). When the temperature in warming mode exceeds $70^{\circ} \mathrm{C}$, the rice made

\footnotetext{
${ }^{2}$ Sanyo developed a variable ultrasonic boiling rice cooker, that by changing the boiling pressure between 1 and 1.2 atm alternatively, it can make the rice "dance" and stream even more thoroughly. Furthermore, it is equipped with "flavor circulation unit" in the lid that able to keep the flavor in without evaporating it to the air.

${ }^{3}$ A total of 599 samples
} 
will be dry, hard and change color, whereas the rice will spoil due to bacterial propagation if it goes below $60^{\circ} \mathrm{C}$. To guarantee the safety of cooked rice and to prevent spoilage, manufacturers have in the past neglected energy efficiency. Therefore, in previous models, rice was kept at around $70^{\circ} \mathrm{C}$ in warm mode. In recent years, manufacturers have developed a "low temperature warming method", in which the temperature of the warm mode, normally set at around $60^{\circ} \mathrm{C}$, is increased to over $70^{\circ} \mathrm{C}$ every several hours to prevent bacterial propagation. This development has allowed manufacturers to take energy savings into consideration.

From the comparison of the average electricity consumption of IH electric rice cookers (1.0L) in warm mode in 1993 and 2004 (Table 14), the efficiency of the rice cookers in warm mode has improved approximately 12 percent in 11 years.

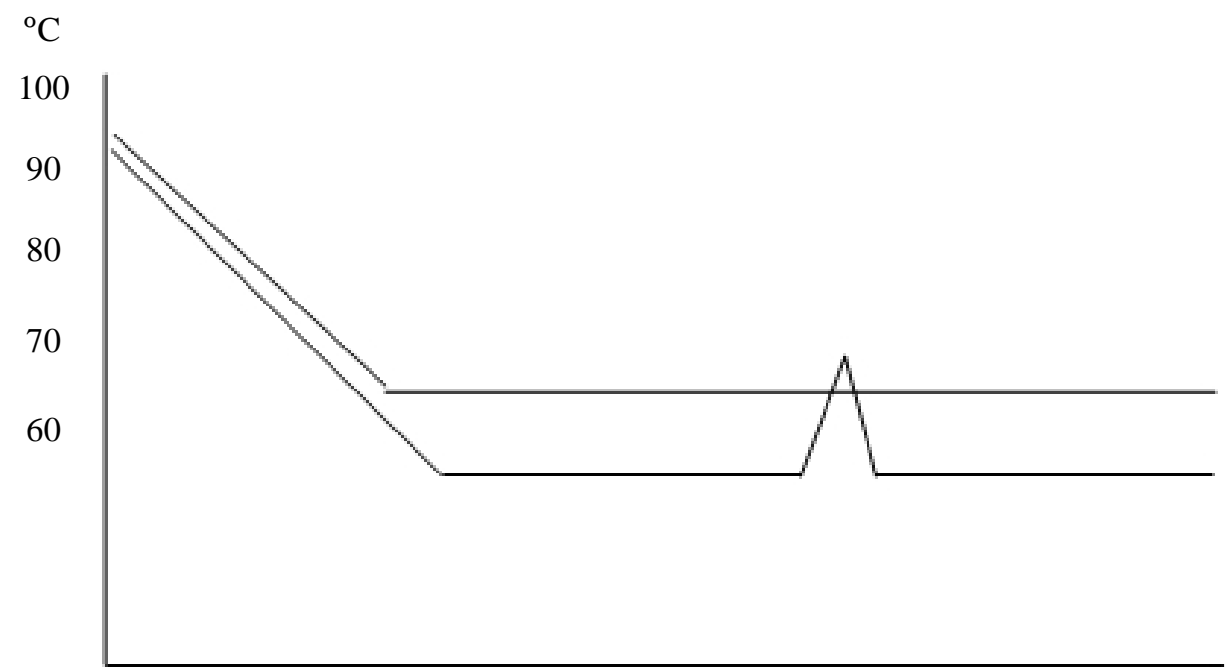

Figure 5 Principle of Operation of Low Temperature Warming Method

Table 14 Average Electric Consumption in Warm Mode for Electric Rice Cookers (IH Type, 1.0L)

\begin{tabular}{|l|l|}
\hline Fiscal Year & Power Consumption in Warm Mode (W) \\
\hline 1993 & 31.0 \\
\hline 2004 & 27.3 \\
\hline
\end{tabular}

Note: The average value is calculated from the values listed in the catalogs of all manufacturers. The measurement method is based on the Japan Electrical Manufacturers' Association's independent standard HD-0057.

\subsubsection{Energy Saving in Standby Mode}

Standby power consumption is important for energy saving. Recently, the Japan Electronics and Information Technology Industries Association (JEITA), the Japan Refrigeration and Air Conditioning Industry Association (JRAIA), and the Japan Electrical Manufacturers' Association (JEMA) jointly announced a plan to reduce power consumption in standby mode. They self-declared that standby power consumption should be reduced to as low as zero for products without timers and $1 \mathrm{~W}$ or less for products with timers by the end of fiscal year 2003 (for air conditioners by the end of Sep- 
tember 2004. To fulfill the declaration, all manufacturers have made improvements to the control circuits and $100 \%$ have achieved the target.

\subsubsection{Transition from Heater Type Electric Rice Cookers to IH Type}

In the past, compared with gas rice cookers, electric rice cookers were less appealing because it was believed that the weak heating power will undermine taste of cooked rice, despite the convenience of electric cookers' timer and warming modes. The IH electric rice cooker was developed in 1988 to tackle this issue, as the IH type cooker heats its pot directly through electromagnetic induction, yielding a higher heating performance than heating through thermal conduction. However, in order to make the taste of cooked rice more competitive with that of the gas rice cookers, the rated power of IH electric rice cookers has been increased. As a result, power consumption of IH electric rice cookers has become greater than the heater types'.

Even though IH type rice cookers are much more costly than heater type (Table 15), they are gaining more popularity among consumers, as the consumers in Japan place a greater priority on the deliciousness of cooked rice over the cost of the cooker.

Table 15 Average Retail Price of IH and Heater Type Rice Cookers

\begin{tabular}{|l|l|l|l|l|}
\hline \multirow{2}{*}{ Type } & \multicolumn{2}{|c|}{ IH Type } & \multicolumn{2}{c|}{ Heater Type } \\
\hline Capacity & $1.0 \mathrm{~L}$ & $1.8 \mathrm{~L}$ & $1.0 \mathrm{~L}$ & $1.8 \mathrm{~L}$ \\
\hline Retail Price Range & $\begin{array}{l}\text { Approx.31,300 } \\
\text { yen }\end{array}$ & $\begin{array}{l}\text { Approx.33,500 } \\
\text { yen }\end{array}$ & $\begin{array}{l}\text { Approx.8,700 } \\
\text { yen }\end{array}$ & Approx.10,500 yen \\
\hline
\end{tabular}

Note: Average retail price at a certain volume outlet

\subsubsection{Future Tasks and Issues on Energy Saving in Electric Rice Cookers}

Rice is cooked by adding heat to raw rice and water to induce chemical changes in the starch. It requires a fixed amount of heat energy, and a decrease in this heat energy may cause unevenness in cooked rice and a less appealing taste. With today's technology, it is difficult to obtain a dramatic improvement in the efficiency of heaters, thus it is likely that further energy savings will be achieved only if the deliciousness of cooked rice is sacrificed. Therefore, it is suggested that it may be necessary to establish a regulatory category which mandates that manufacturers increase energy savings without losing the taste of the cooked rice. For instance, if the proportion of added water is decreased, energy savings can be achieved from the decrease of evaporated water and power consumption accordingly; however, the rice may be undercooked in some cases as a result. If rice cooker products with lower water use are set as Top Runner products, it is likely that only electric rice cookers that may undercook rice will remain in the market, as the Top Runner status will set a limit on how much water manufacturers can tell consumers to add to their rice cookers. To avoid this happening, the establishment of separate categories for products whose proportion of adding water falls outside of the current allowed distribu- 
tion may be necessary. This can enable a reliable regulatory system while giving manufactures the market incentive to develop further advanced technologies to achieve both deliciousness of cooked rice and energy saving.

\subsection{Energy Saving Label}

Other than Top-runner Program, Rice cookers have also been included to the Energy Conservation Program. The Label Display Program was lunched as a part of the labeling program, and is to make the voluntary labeling program mandatory for retailers. The voluntary labeling program was launched in Japan in August 2000, which covers 16 products as of December 2007 (Figure 6). In April 2006, the revised Law Concerning the Rational Use of Energy that stipulates the obligation of retailers to make efforts to provide information went into effect, and a guideline was developed by the Retailer Evaluation Standard Subcommittee under Natural Resources and Energy. It mandates that retailers provide information of products at their stores using the "National standard Energysaving Label" which includes information such as energy consumption and expected electricity cost (Figure 7).

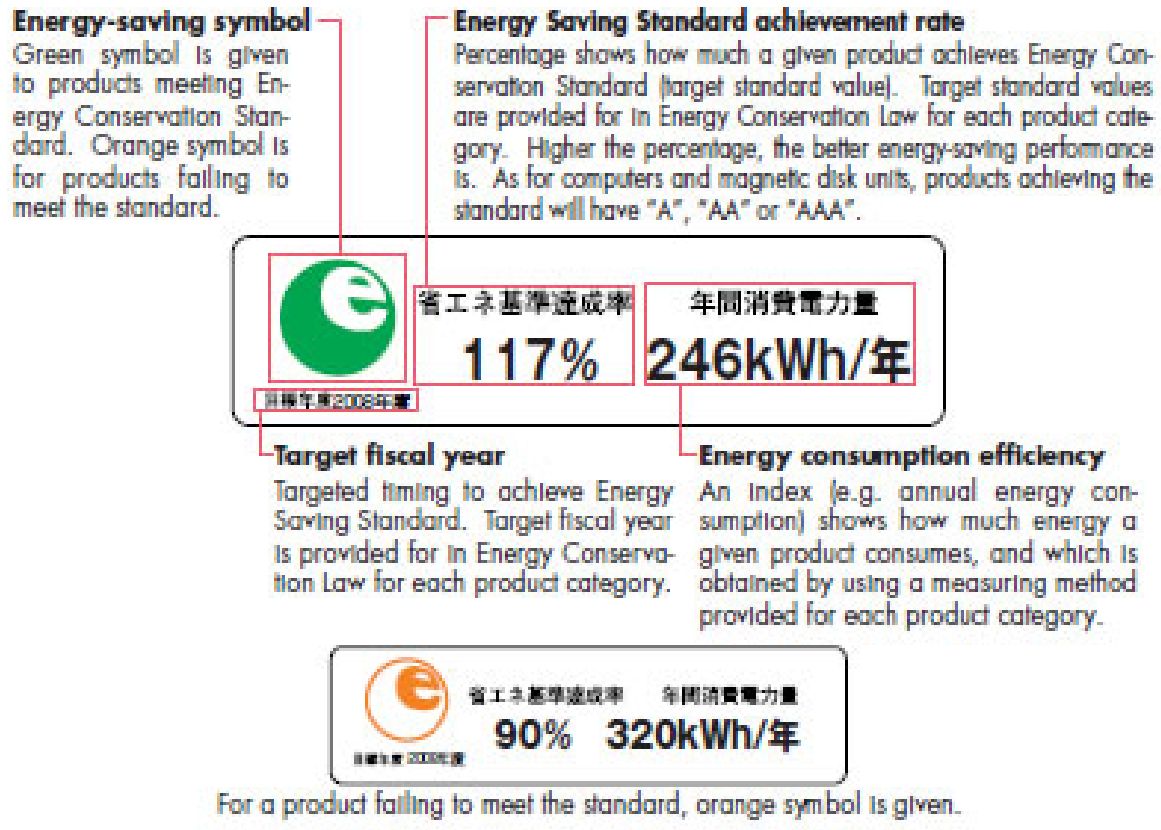

Figure 6 The Symbol of Energy Saving Label 


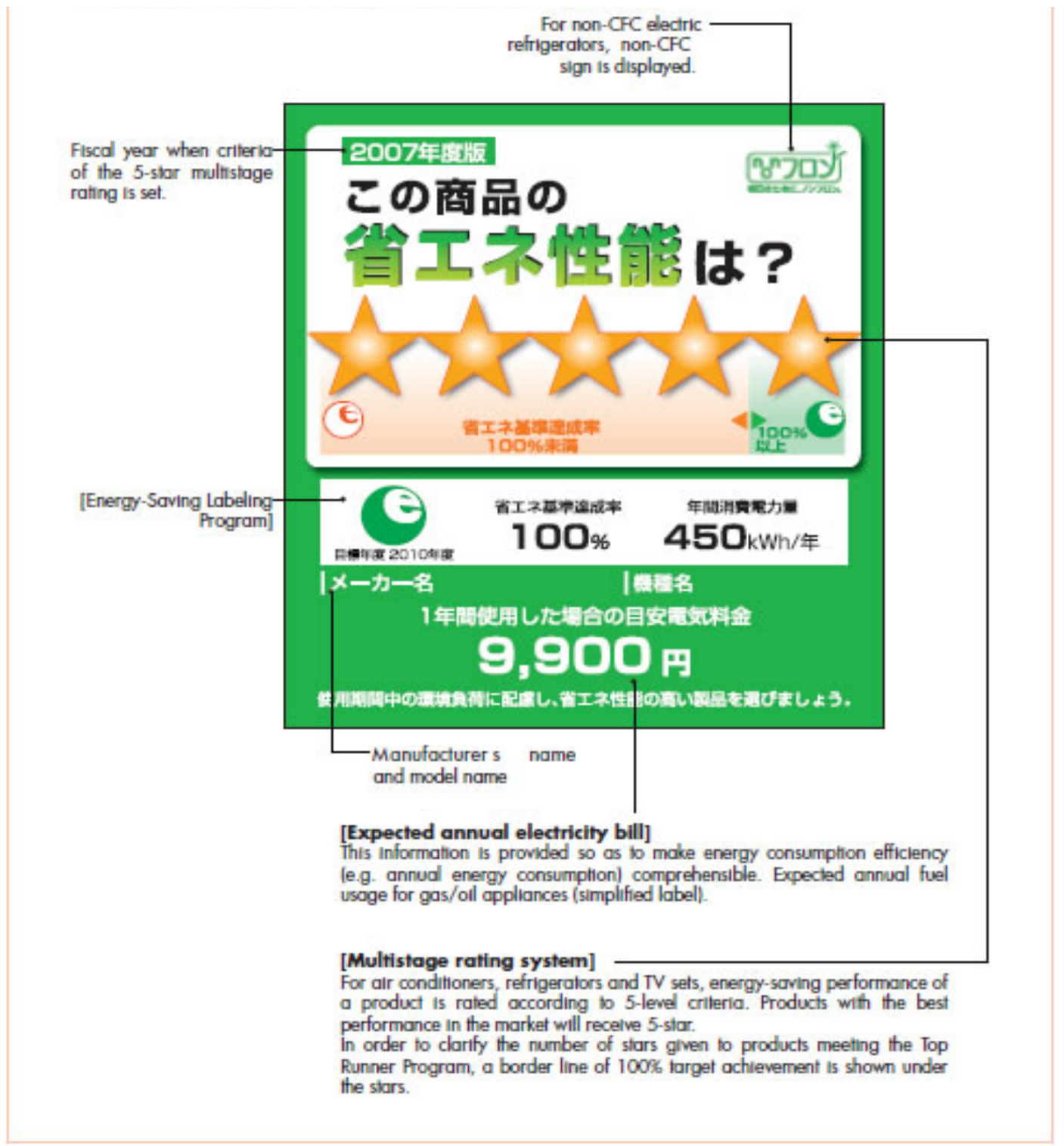

Source: $\underline{\text { http://www.eccj.or.jp/top_runner/e_05.html\#03 }}$, ECCJ

\section{Figure 7 Label of Label Display Program for Retailers}

\subsection{Energy Efficient Rice Cooker Database}

The Energy Conservation Center of Japan (IEEJ) releases energy saving product database on the web regularly, on which the energy saving performance of each product is listed and ranked ${ }^{4}$. The database include the manufacturer, type, model of product, energy saving performance, annual estimated electricity consumption, and annual electricity costs. The annual electricity consumption is calculated based on the following formula:

Annual electricity consumption = cooking electricity consumption + warming electricity consumption + on timer annual electricity consumption + standby electricity consumption

\footnotetext{
${ }^{4}$ http://www.eccj.or.jp/catalog/2007w-h/rice/index.html
} 
The database is categorized by size of the rice cooker and different type of the heating system, since IH type was designed to improve the taste of cooked rice, but tend to use more energy.

Table 16 presents an example of energy performance of IH rice cookers in 5.5-8 cup (1 L to $1.44 \mathrm{~L}$ ) capacity category, and Table 17 shows the same category for microcomputer type rice cookers. The average annual electricity consumption of an $\mathrm{IH}$ type rice cooker is $110.9 \mathrm{kWh} /$ year, the most efficient model consumes $92 \mathrm{kWh} /$ year, and the ratio of energy saving standard achievement is $98 \%$, whereas the least efficient model consumes $39 \%$ more energy and the achievement ratio is only $76 \%$. Among the 58 listed models, the distribution of the energy consumption is relatively even, and energy consumption in $101-110 \mathrm{kWh}$ bin is higher than other bins at 29\% (Figure 8). In the case of micro computer type, the average energy consumption is $101 \mathrm{kWh}, 10 \%$ less that of the IH type. The most efficient model consumes $84.5 \mathrm{kWh} /$ year energy, $84 \%$ that of the average efficiency. More products with greater energy consumption were observed than those in the lower energy consumption bins (Figure 9). Among the energy used in different modes, cooking uses most of the energy. The electricity consumption in cooking mode and keeping warm mode varies significantly among different models.

However, even though some models are very close to achieving the target, only one microcomputer model actually achieved the energy saving target stated in the Top-runner program. Possible reasons include that the Japanese manufactures developed many technologies to improve the deliciousness of the cooked rice, which resulted in more energy consumption. The Top-runner target may be set at the base of the products that use less added water and therefore less energy, but sacrificed the taste of cooked rice. Because the Japanese consumers place priority on the taste of rice cooked, many technology improvements were made with that focus, thus resulted in relatively higher energy consumption. Japan is facing the dilemma in further technology development, some suggestions made includes creating a separate category for Top-runner program.

Average electricity cost for IH type is estimated to be 2,441 Yen/year $(\$ 23.5 / \text { year })^{5}$, and 2,222 Yen/year (\$21.4/year) for microcomputer type.

51 yen $=0.00963$ dollars in April, 2008 
Table 16 5.5-8 Cup (1 L to 1.44L) IH Type Rice Cooker Technologies and Energy Performance in Japan

\begin{tabular}{|c|c|c|c|c|c|c|c|c|c|c|c|}
\hline \multirow[b]{2}{*}{ Rank } & \multirow[b]{2}{*}{ Manufacturer } & \multirow[b]{2}{*}{ Model } & \multicolumn{3}{|c|}{ Energy Saving Labeling Program ( $\left.{ }^{* 1}\right)$} & \multirow[b]{2}{*}{$\begin{array}{c}\text { Electricity } \\
\text { bill } \\
\text { (Yen/Year) }\end{array}$} & \multirow[b]{2}{*}{$\begin{array}{c}\text { Maximum } \\
\text { cooking } \\
\text { capacity (L) }\end{array}$} & \multicolumn{4}{|c|}{ Electricity consumption } \\
\hline & & & $\begin{array}{l}\text { Energy } \\
\text { Saving } \\
\text { Label }\end{array}$ & $\begin{array}{l}\text { Energy saving } \\
\text { standard } \\
\text { achivement }\end{array}$ & $\begin{array}{c}\text { Annual } \\
\text { electricity } \\
\text { consumption } \\
\text { (kWh/vear) }\end{array}$ & & & $\begin{array}{c}\text { Cooking } \\
\text { mode } \\
\text { (Wh/time) }\end{array}$ & $\begin{array}{c}\text { Keeping } \\
\text { warm mode } \\
(\mathrm{Wh} / \mathrm{h})\end{array}$ & $\begin{array}{l}\text { Timer } \\
\text { mode } \\
(\mathrm{Wh} / \mathrm{h})\end{array}$ & $\begin{array}{c}\text { Standby } \\
\text { mode } \\
(\mathrm{Wh} / \mathrm{h})\end{array}$ \\
\hline 1 & Zojirushi Mahohbin & NP-JB10-XJ & (e) & 97 & $\frac{92}{9}$ & 2,020 & 1 & 178 & 18.3 & 0.92 & 0.8 \\
\hline 2 & Zojirushi Mahohbin & NP-JX10-XA & e & 94 & 94 & 2,070 & 1 & 177 & 19.5 & 0.99 & 0.88 \\
\hline 3 & Zojirushi Mahohbin & NP-JE10-XA & $\mathbf{e}$ & 95 & 94.5 & 2,080 & 1 & 181 & 18.9 & 0.99 & 0.88 \\
\hline 4 & Zojirushi Mahohbin & NP-LE10-XJ & é & 97 & 95.4 & 2,100 & 1 & 180 & 19.5 & 1.07 & 0.96 \\
\hline 5 & Hitachi & RZ-GG10JS & e & 94 & 95.4 & 2,100 & 1 & 164.6 & 23.1 & 1.36 & 0.74 \\
\hline 6 & Hitachi & RZ-GV100J N & é & 95 & 95.7 & 2,110 & 1 & 158.9 & 24.4 & 1.46 & 0.79 \\
\hline 7 & Hitachi & RZ-GX100J S & 9 & 95 & 95.7 & 2,110 & 1 & 158.9 & 24.4 & 1.46 & 0.79 \\
\hline 8 & Zojirushi Mahohbin & NP-LS10-WP & & 97 & 96.7 & 2,130 & 1 & 184 & 19.5 & 1.07 & 0.96 \\
\hline 9 & Zojirushi Mahohbin & NP-LA10-SP & $E$ & 97 & 96.7 & 2,130 & 1 & 184 & 19.5 & 1.07 & 0.96 \\
\hline 10 & Zojirushi Mahohbin & NP-HC10-XJ & & 94 & 97 & 2,130 & 1 & 188 & 19.1 & 0.99 & 0.88 \\
\hline 11 & Hitachi & RZ-GD10JN & 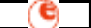 & 92 & 97.5 & 2,150 & 1 & 163.5 & 24.8 & 1.36 & 0.74 \\
\hline 12 & Mitsubishi & NU-SE10-S & e & 94 & 98.1 & 2,160 & 1 & 181.4 & 21 & 1.2 & 0.9 \\
\hline 13 & Mitsubishi & NJ-HM10-S & e & 93 & 100.4 & 2,210 & 1 & 174.9 & 24.3 & 0.9 & 0.8 \\
\hline 14 & Mitsubishi & NU-SV10-S & e & 92 & 102.4 & 2,250 & 1 & 193.9 & 21 & 1.2 & 0.9 \\
\hline 15 & Toshiba & RC-10NF-WT & 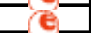 & 94 & 103 & 2,270 & 1 & 187 & 23.5 & 0.77 & 0.68 \\
\hline 16 & Tiger Mahohbin & JKC-S100-H & & 91 & 103 & 2,270 & 1 & 180 & 24.7 & 0.9 & 0.8 \\
\hline 17 & Tiger Mahohbin & JKC-J100-H & & 91 & 103 & 2,270 & 1 & 180 & 24.7 & 0.9 & 0.8 \\
\hline 18 & Toshiba & RC-10NHS & 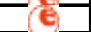 & 90 & 104 & 2,290 & 1 & 188 & 24 & 0.89 & 0.81 \\
\hline 19 & Mitsubishi & NJ-SX10-T & e & 90 & 104 & 2,290 & 1 & 198.7 & 21 & 1.2 & 0.9 \\
\hline 20 & Mitsubishi & NJ-WS10A-K & & 91 & 105 & 2,310 & 1 & 185.6 & 24.6 & 1.1 & 0.9 \\
\hline 21 & National & SRHE101-P & $E$ & 98 & 107 & 2,350 & 1 & 216 & 20 & 1.2 & 0.63 \\
\hline 22 & National & SR-HG101-N & & 98 & 107 & 2,350 & 1 & 218 & 19.3 & 1.2 & 0.63 \\
\hline 23 & Tiger Mahohbin & JKD-H100-H & e & 95 & 107 & 2,350 & 1 & 202 & 23.1 & 0.8 & 0.7 \\
\hline 24 & Tiger Mahohbin & JKD-G100-WU & e & 93 & 108 & 2,380 & 1 & 198 & 24.3 & 0.8 & 0.7 \\
\hline 25 & National & SR-SX10-N & e & 95 & 108.5 & 2,390 & 1 & 228 & 22 & 0.783 & 0.667 \\
\hline 26 & National & SR-HS101-C & 7 & 97 & 109 & 2,400 & 1 & 221 & 20.1 & 1.2 & 0.63 \\
\hline 27 & National & SR-SD10-S & 5 & 95 & 109.3 & 2,410 & 1 & 232 & 22 & 0.786 & 0.672 \\
\hline 28 & National & SR-SE101-S & $\mathrm{E}$ & 96 & 109.7 & 2,410 & 1 & 225 & 19.7 & 0.79 & 0.67 \\
\hline & National & SR-SE101-R & & 96 & 109.7 & 2,410 & 1 & 225 & 19.7 & 0.79 & 0.67 \\
\hline 30 & National & SRSY101-N & & 97 & 109.8 & 2,420 & 1 & 227 & 19.2 & 0.79 & 0.67 \\
\hline 31 & Tiger Mahohbin & JKF-G100-TG & & 87 & 110 & 2,420 & 1 & 203 & 24.5 & 0.8 & 0.7 \\
\hline 32 & Sanyo & ECJ-IZ10(SP) & e & 91 & 110.5 & 2,430 & 1 & 217.7 & 22.6 & 0.4 & 0.4 \\
\hline 33 & Sanyo & ECJ-IK10(SN) & e & 89 & 111 & 2,440 & 1 & 222 & 22 & 0.4 & 0.4 \\
\hline 34 & National & SR-SW101-W & é & 95 & 112 & 2,460 & 1 & 236 & 20.5 & 0.13 & 0.1 \\
\hline 35 & National & SR-SW101-T & e. & 95 & 112 & 2,460 & 1 & 236 & 20.5 & 0.13 & 0.1 \\
\hline 36 & Zojirushi Mahohbin & NP-DA10-SA & 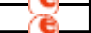 & 89 & 112 & 2,460 & 1 & 202 & 25.6 & 0.99 & 0.88 \\
\hline 37 & Tiger Mahohbin & JKF-S100-KS & e. & 85 & 113 & 2,490 & 1 & 208 & 24.7 & 1.1 & 1 \\
\hline 38 & Tiger Mahohbin & JKF-H100-CU & $\mathrm{e}$ & 85 & 113 & 2,490 & 1 & 207 & 25.4 & 0.8 & 0.7 \\
\hline 39 & Sanyo & ECJ-IG10(SW) & $E$ & 88 & 113.7 & 2,500 & 1 & 209.9 & 25.8 & 0.7 & 0.6 \\
\hline 40 & National & SR-SU101-N & 2 & 93 & 115 & 2,530 & 1 & 244 & 20.4 & 0.13 & 0.1 \\
\hline 41 & Tiger Mahoh-bin & JKG-G100-H & e & 83 & 115 & 2,530 & 1 & 222 & 23.7 & 0.7 & 0.6 \\
\hline 42 & Zojirushi Mahohbin & NP-HX10-XJ & & 81 & 116.2 & 2,560 & 1 & 221 & 24.2 & 0.99 & 0.88 \\
\hline 43 & Toshiba & RC-10MF-WT & eे & 84 & 116.4 & 2,560 & 1 & 197.4 & 30 & 0.8 & 0.7 \\
\hline 44 & National & SR-A10N-S & e & 92 & 116.5 & 2,560 & 1 & 224.9 & 24.2 & 1 & 0.54 \\
\hline 45 & National & SR-ST10A-SW & e. & 95 & 116.8 & 2,570 & 1 & 251 & 20.15 & 0.1256 & 0.0982 \\
\hline 46 & National & SR-SS10A-W & $\mathrm{e}$ & 93 & 117.4 & 2,580 & 1 & 251.5 & 20.45 & 0.124 & 0.0952 \\
\hline 47 & Toshiba & RC-10MX-SS & é & 83 & 117.5 & 2,590 & 1 & 215.6 & 25 & 0.9 & 0.8 \\
\hline 48 & National & SR-A10S-W & e & 90 & 118.1 & 2,600 & 1 & 224 & 25.4 & 1 & 0.54 \\
\hline 49 & Toshiba & RC-10VT-SS & & 80 & 120 & 2,640 & 1 & 216.2 & 27 & 1 & 0.7 \\
\hline 50 & Toshiba & RC-10VSA-SS & $\in$ & 80 & 120 & 2,640 & 1 & 220 & 26.9 & 1.4 & 0.87 \\
\hline 51 & Toshiba & RC-10VS-SS & e & 80 & 120.7 & 2,660 & 1 & 215.9 & 26 & 1 & 0.9 \\
\hline 52 & Toshiba & RC-10NY-SS & e & 80 & 121 & 2,660 & 1 & 218 & 28.2 & 0.88 & 0.74 \\
\hline 53 & Toshiba & RC-10WW-SS & e & 79 & 121.2 & 2,670 & 1 & 212.9 & 27 & 1 & 0.9 \\
\hline 54 & Toshiba & RC-10MG-S & e & 82 & 121.3 & 2,670 & 1 & 206.5 & 29 & 1 & 0.9 \\
\hline 55 & Toshiba & RC-10MY-SS & e. & 80 & 121.5 & 2,670 & 1 & 216.8 & 27 & 0.9 & 0.8 \\
\hline 56 & Zojirushi Mahohbin & NP-EC10-WB & 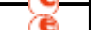 & 81 & 121.6 & 2,680 & 1 & 209 & 30.2 & 1.06 & 0.94 \\
\hline 57 & Hitachi & RZ-ES10W & e & 77 & 121.6 & 2,680 & 1 & 194.1 & 33.5 & 1.4 & 0.78 \\
\hline 58 & Tiger Mahohbin & JKC-R100-KS & é & 84 & 122 & 2,680 & 1 & 226 & 26.8 & 0.9 & 0.8 \\
\hline 59 & Tiger Mahohbin & JKC-W100-KS & & 84 & 122 & 2,680 & 1 & 226 & 26.8 & 0.9 & 0.8 \\
\hline 60 & Toshiba & RC-10WWA-SS & e & 80 & 122 & 2,680 & 1 & 221 & 27.3 & 1.4 & 0.87 \\
\hline 61 & Sanyo & ECJ-XP10(W) & e & 80 & 122.1 & 2,690 & 1 & 221.6 & 28.4 & 0.8 & 0.7 \\
\hline 62 & Sanyo & ECJ-XV10(N) & e & 80 & 123.1 & 2,710 & 1 & 228.4 & 27.8 & 0.7 & 0.6 \\
\hline 63 & Tiger Mahohbin & JKF-B100-CU & e & 85 & 125 & 2,750 & 1 & 251 & 23.7 & 0.8 & 0.7 \\
\hline 64 & Zojirushi Mahohbin & NP-KA10-WB & e & 76 & 126 & 2,770 & 1 & 210 & 32.8 & 1.06 & 0.94 \\
\hline 65 & Toshiba & RC-10VXA(SS) & e) & 77 & 126.8 & 2,790 & 1 & 228 & 29.6 & 0.99 & 0.85 \\
\hline 66 & Tiger Mahohbin & JKF-A100-KS & (e) & 83 & 128 & 2,820 & 1 & 249 & 25.5 & 1 & 0.9 \\
\hline \multicolumn{3}{|c|}{ Maximum } & & 76 & 128 & 2,820 & 1 & 252 & 33.5 & 1.5 & 1 \\
\hline & Average & & & 89 & 110.9 & 2,441 & 1 & 208 & 23.9 & 0.914 & 0.719 \\
\hline & Minimun & & & 98 & 92 & 2,020 & 1 & 159 & 18.3 & 0.124 & 0.0952 \\
\hline
\end{tabular}


Table 17 5.5-8 Cup Microcomputer Type Rice Cooker Technologies and Energy Performance in Japan

\begin{tabular}{|c|c|c|c|c|c|c|c|c|c|c|c|}
\hline \multirow[b]{2}{*}{ Rank } & \multirow[b]{2}{*}{ Manufacturer } & \multirow[b]{2}{*}{ Mbdel } & \multicolumn{3}{|c|}{ Energy Saving Labeling Program ( ${ }^{*}$ ) } & \multirow[b]{2}{*}{$\begin{array}{c}\text { Eectricity } \\
\text { bill } \\
\text { (Yen/Year) }\end{array}$} & \multirow[b]{2}{*}{$\begin{array}{l}\text { Maximum } \\
\text { cooking } \\
\text { capacity(L) }\end{array}$} & \multicolumn{4}{|c|}{ Eectricity consumption } \\
\hline & & & $\begin{array}{l}\text { Energy } \\
\text { Saving } \\
\text { Label }\end{array}$ & $\begin{array}{l}\text { Energy saving } \\
\text { standard } \\
\text { achivement }\end{array}$ & $\begin{array}{c}\text { Amual } \\
\text { electricity } \\
\text { consumption } \\
\text { (kWher }\end{array}$ & & & $\begin{array}{l}\text { Cooking } \\
\text { mode } \\
\text { (Wh/time) }\end{array}$ & $\begin{array}{c}\text { Keeping } \\
\text { wermmode } \\
(\mathrm{Wh} / \mathrm{h})\end{array}$ & $\begin{array}{l}\text { Timer } \\
\text { mode } \\
\text { (Wh/h) }\end{array}$ & $\begin{array}{c}\text { Stanclby } \\
\text { mode } \\
(\mathrm{Wh} / \mathrm{h})\end{array}$ \\
\hline 1 & Zojinushi Mahohbin & NS-TB10-XA & (e) & $\frac{\operatorname{late}(\mathrm{a})}{99}$ & \begin{tabular}{|c|} 
hingean \\
84.5
\end{tabular} & 1860 & 1 & 160 & 18.1 & 0.68 & 0.56 \\
\hline 2 & Zojinushi Mahohbin & NS-WA10-WB & e & 98 & 86.1 & 1890 & 1 & 159 & 19.1 & 0.68 & 0.56 \\
\hline & Zojinushi Mahohbin & NSWE10-WB & e & 98 & 86.1 & 1890 & 1 & 159 & 19.1 & 0.68 & 0.56 \\
\hline 4 & Sharp & KS-FA10-C & G & 100 & 91.9 & 2020 & 1 & 178.7 & 18.5 & 1.11 & 0.45 \\
\hline 5 & Tiger Mahohbin & JAGA100-TM & $\hat{\mathrm{e}}$ & 93 & 95.1 & 2090 & 1 & 172 & 229 & 0.3 & 0.3 \\
\hline 6 & Tiger Mahohbin & JAGB100-WL & e & 93 & 95.8 & 2110 & 1 & 174 & 229 & 0.3 & 0.3 \\
\hline 7 & National & SRIF10-W & $E$ & 88 & 1023 & 2250 & 1 & 17227 & 26.83 & 0.629 & 0.547 \\
\hline 8 & National & SRNC1O-W & & 89 & 1024 & 2250 & 1 & 173.33 & 26.45 & 0.715 & 0.637 \\
\hline 9 & Htachi & RZ-AM10W & & 85 & 103.5 & 2280 & 1 & 1725 & 27.5 & 0.59 & 0.5 \\
\hline 10 & Zojinushi Mahohbin & NSTGO-XA & & 82 & 108 & 2380 & 1 & 187 & 27.1 & 0.68 & 0.56 \\
\hline 11 & Tsann Kuen JAPAN & TSK-MRC110 & 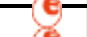 & 80 & 111.3 & 2450 & 1 & 608 & 91 & 0.7 & 0.7 \\
\hline 12 & Sharp & KS-F105-W & e- & 80 & 111.6 & 2460 & 1 & 191.3 & 28.4 & 1.1 & 0.49 \\
\hline 13 & Toshiba & RC-10NMF-WT & e) & 76 & 117.3 & 2580 & 1 & 186.1 & 31 & 0.9 & 0.7 \\
\hline 14 & Toshiba & RG-10NMDWT & e) & 75 & 118.3 & 2600 & 1 & 189.1 & 32 & 0.8 & 0.7 \\
\hline \multicolumn{3}{|c|}{ Maximum } & & 75 & 118.3 & 2600 & 1 & 608 & 91 & 1.11 & 0.7 \\
\hline \multicolumn{3}{|c|}{ Average } & & 88 & 101 & 2222 & 1 & 206 & 29.3 & 0.705 & 0.54 \\
\hline \multicolumn{3}{|c|}{ Mnimum } & & 100 & 84.5 & 1860 & 1 & 159 & 18.1 & 0.3 & 0.3 \\
\hline
\end{tabular}

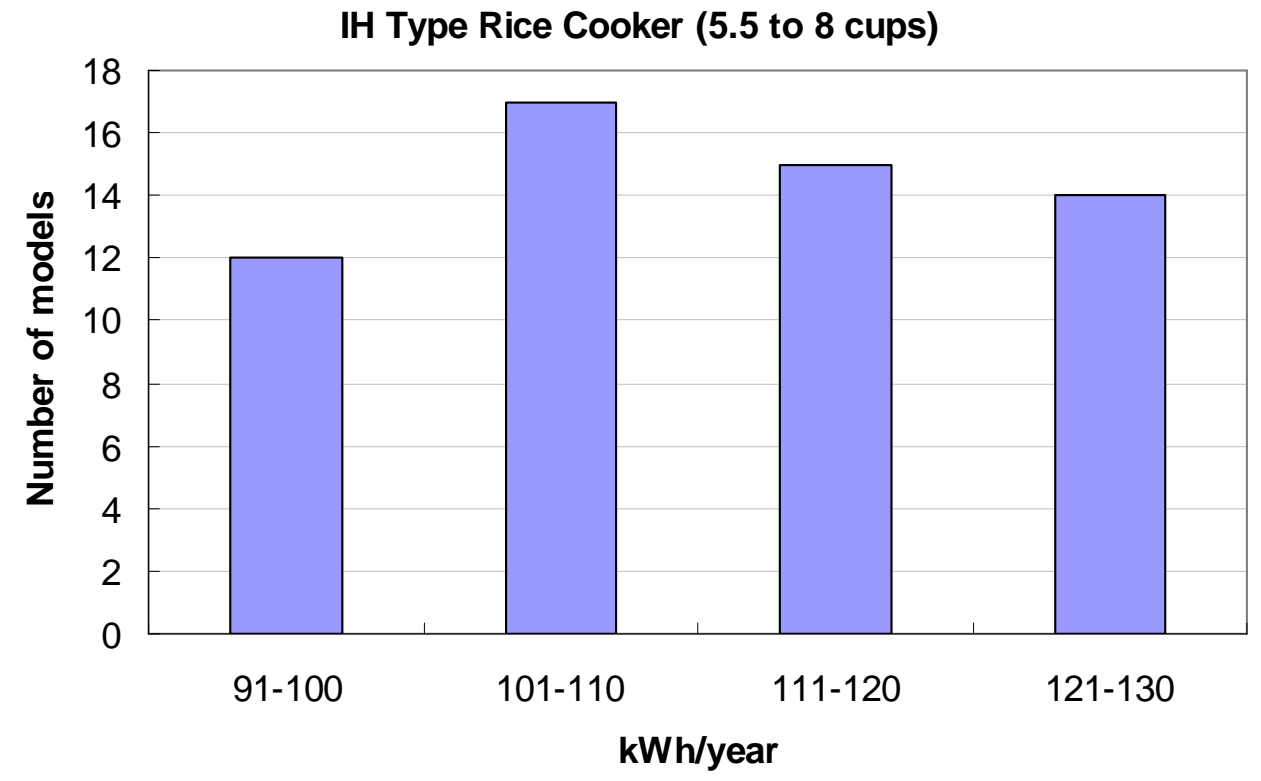

Figure 8 Distribution of the Energy Consumption of IH Type Rice Cookers 
Microcumputer Type Rice Cooker (5.5 to 8 cups)

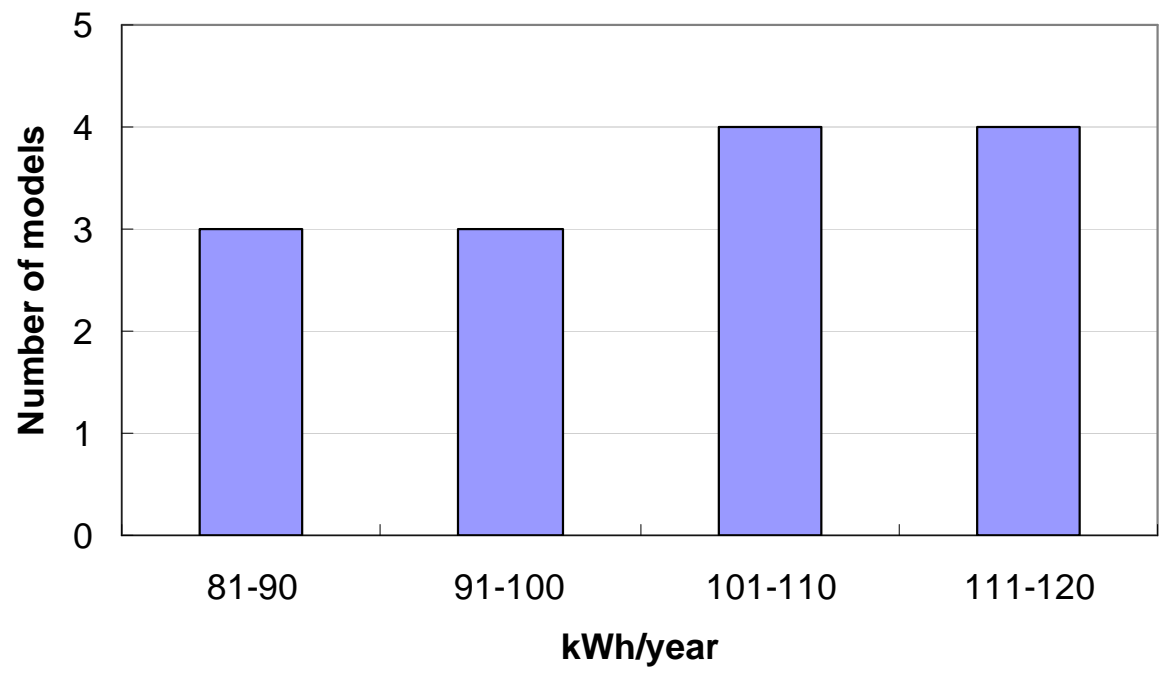

Figure 9 Distribution of the Energy Consumption of Microcumputer Type Rice Cookers

\subsection{Energy Saving Technologies}

As discussed above, energy saving has not been a priority for rice cooker technology development in Japan, there have been efforts made to improve the energy efficiency while developing various technologies to improve the deliciousness of cooked rice. Energy saving in rice cookers mostly rest with insulation of the pot. A Vacuum Pressure IH Rice Cooker was developed to provide thin vacuum layers on both sides as with the vacuum bottle, so that the heat can be kept inside the pot. In addition, it artificially increases the internal pressure of the pot in the process of cooking to increase the sweetness of the rice, but can simultaneously seal off the internal air thus saves the energy (Figure 10). Zojirushi claims that using this technology can save 10\% of the energy used for cooking and $12 \%$ for keeping warm ${ }^{6}$
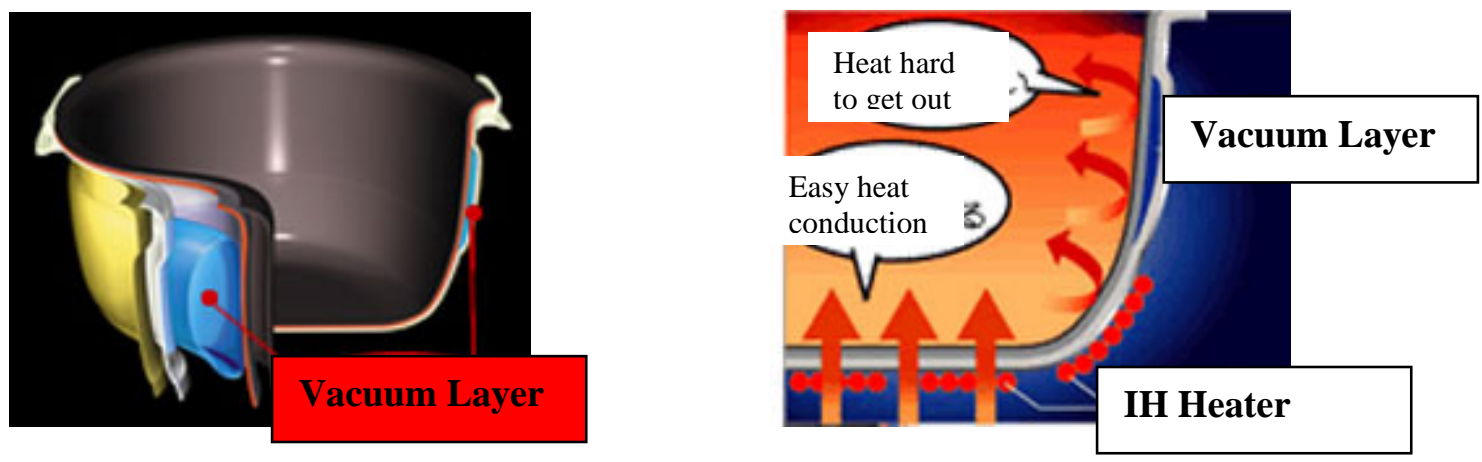

Source: http://www.zojirushi.co.jp/syohin/ricecooker/NPHT.html

Figure 10 The Image of the Zojirushi Vacuum Oven Pot Rice Cooker

\footnotetext{
${ }^{6}$ http://www.nc-news.com/frame/20030707/kigy030707.htm, and http://www.jemanet.or.jp/Japanese/denki/2007/de-0702/p30-32.pdf
} 
Other technologies include Matsushita's highly efficient induction heating system using a voltage-fed single-ended resonant inverter with low energy loss, a heating coil with minimal resistance at high frequencies, and a rice cooking pot featuring a copper-plated layer of optimal thickness (Figure ) to improve the heat conducted from the IH heater. Matsushita also developed a technology that has a double stainless layer lid, in which the entire lid can be heated and steam runs in between the two layers can reach $130^{\circ} \mathrm{C} 1.4$ times faster (Figure12,13) .

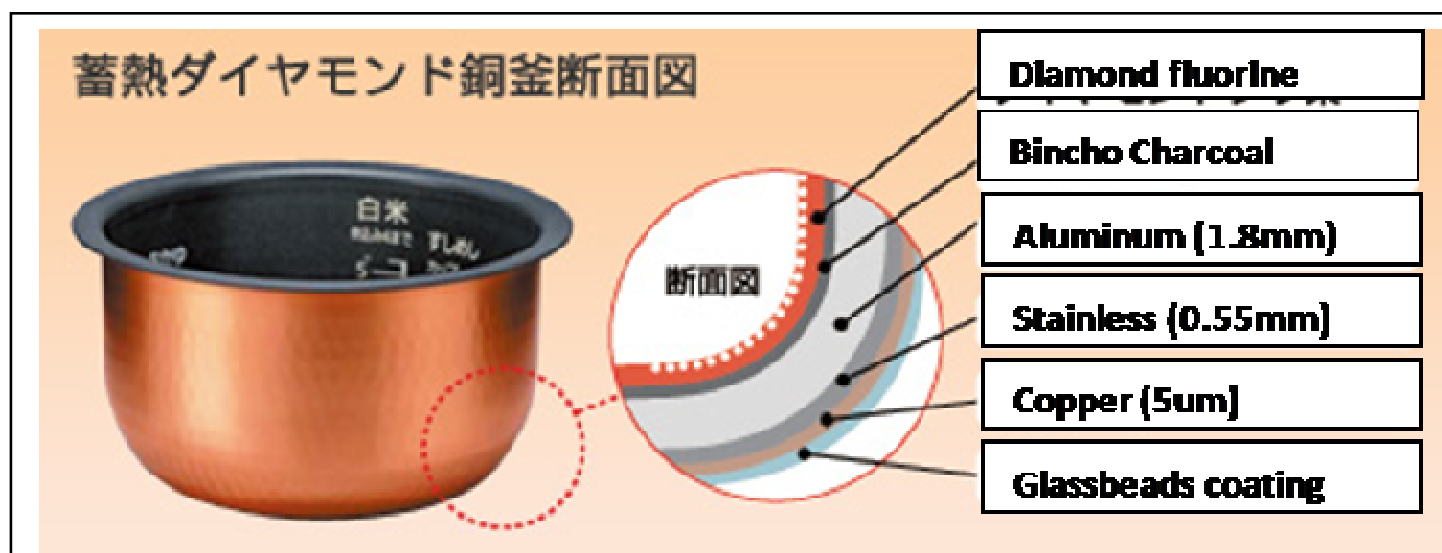

Figure 11 Heat Storage Diamond Copper Pot

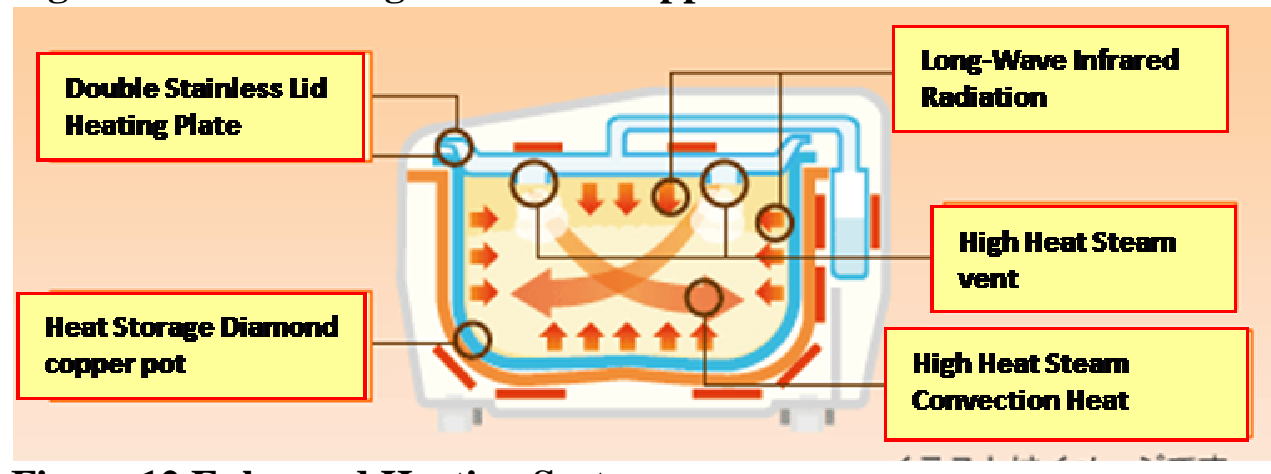

Figure 12 Enhanced Heating System

Source: Matsushita, http://ctlg.national.jp/product/



Figure 12 Double Stainless Lid 
Toshiba has also developed vacuum insulation structure that uses aluminum to seal a $3 \mathrm{~mm}$ thick vacuum in the glass wool insulation, and the thermal conductivity is $1 \mathrm{~mW} /(\mathrm{mK})^{7}$.

\section{Conclusion}

This report aims to examine the rice cooker standards and labeling programs in countries outside of China, in assisting China to revise its rice cooker standard that is expected to be effective in 2009. The report consists of an overview of rice cooker standards and labeling programs and testing procedures in Hong Kong, South Korea, Japan and Thailand, and Japan's case study in developing energy efficiency rice cooker technologies and rice cooker efficiency programs. The results from the analysis can be summarized as the follows:

Hong Kong has a Voluntary Energy Efficiency Labeling scheme for electric rice cookers initiated in 2001, with revision implemented in 2007. The program applies to rice cookers with maximum cooking capacity of 3.6 liters and rated power consumption of $2 \mathrm{~kW}$; South Korea has both MEPS and Mandatory Energy Efficiency Label targeting the same category of rice cookers as Hong Kong; Thailand's voluntary endorsement labeling program is similar to Hong Kong in program design but has 5 efficiency grades. Japan's program is distinct in its adoption of the "Top Runner" approach, in which, the future efficiency standards is set based on the efficiency levels of the most efficient product in the current domestic market. Although the standards are voluntary, penalties can still be evoked if the average efficiency target is not met. For rice cookers, it does not set the maximum cooking capacity, but excludes capacities below $0.54 \mathrm{~L}$, and cookers for industrial use.

Regarding on the test procedures, both Hong Kong and South Korea's tests involve pouring water into the inner port equal to $80 \%$ of its rated volume; however, white rice is used as a load for its tests in Hong Kong whereas no rice is used for tests in South Korea. In Japan's case, water level specified by the manufactures is used and milled rice is used as a load only partially in the tests. Moreover, Japan does not conduct heat efficiency test but its energy consumption measurements tests are much more complex, with 4 different tests are conducted to determine the annual average energy consumption.

Hong Kong and Thailand both set Minimum Allowable Heat Efficiency for different Rated Wattages. The energy efficiency requirements are identical except that the minimum heat efficiency in Thailand is 1 percentage point higher for all rated power categories. In South Korea, MEPS and label's energy efficiency grades are determined by the rice cooker's Rated Energy Efficiency for induction, non-induction, pressure, nonpressure rice cookers. Japan's target standard values are set for electromagnetic induction heating products and non-electromagnetic induction heating products by different size of

\footnotetext{
${ }^{7}$ http://techon.nikkeibp.co.jp/article/NEWS/20060719/119267/
} 
rice cookers. Specific formulas are used by type and size depending on the mass of water evaporation of the rice cookers.

Japan has been the leading country in technology development of various types of rice cookers, and developed concrete energy efficiency standards for rice cookers. Since Induction heating rice cooers were introduced in Japan, the share of IH rice cookers has been increasing steadily, currently accounting for more than half of all rice shipped domestically, and medium size $(0.99 \mathrm{~L}$ to $1.8 \mathrm{~L})$ rice cookers accounts for nearly 60 percent of the total shipments in recent years. However, unlike other appliances in Japan, energy efficiency of rice cookers has not been a focus for technology development. As consumers in Japan emphasize the deliciousness of cooked rice over other factors, many types of models were developed to improve the taste of cooked rice. Nonetheless, the efficiency of IH rice cookers in warm mode has improved approximately 12 percent from 1993 to 2004 due to the "low temperature warming method" developed by manufacturers.

The Energy Conservation Center of Japan (IEEJ) releases energy saving products database on the web regularly, on which the energy saving performance of each product is listed and ranked. The average electricity consumption of an 5.5- 8 cup rice cooker is $110.9 \mathrm{kWh} /$ year for IH type, and $101 \mathrm{kWh} /$ year for micro computer non-IH type. However, most of the technologies have not met the target stated in the Top-runner program.

Energy saving in rice cookers mostly rest with insulation of the pot. Technology developed to improve the energy efficiency of the rice cookers includes providing vacuum layers on both side of the pot, using copper-plated materials, and double stainless layer lid that can be heated and steam can run in between the two layers to speed the heating process.

However the dilemma that Japan is facing is that many technologies developed to improve the taste of the rice, yielding higher energy consumption. Further improvement in energy efficiency conflicts with the pursuit of deliciousness of cooked rice. Some suggests that the establishment of separate categories for products targeting deliciousness of the rice. 


\section{Reference}

The Energy Conservation Center (ECCJ), 2008a.

http://www.eccj.or.jp/top_runner/index_contents_e.html,

The Energy Conservation Center (ECCJ), 2008b. http://www.eccj.or.jp/catalog/2007w$\underline{\mathrm{h} / \text { rice/index.html }}$

Electrical and Mechanical Services Department (EMSD), 2007. The Hong Kong Voluntary Energy Efficiency Labeling Scheme for Electric Rice-Cookers, Electrical and Mechanical Services Department, Hongkong.

http://www.emsd.gov.hk/emsd/eng/pee/eels_sch_doc.shtml

Electric Rice Cooker Criteria Standard Subcommittee (ERCCSS), 2005, Energy Efficiency Standards Subcommittee of the Advisory Committee on Energy and Natural Resources, Final Report on the Top Runner Target Rice Cooker Standards, http://www.eccj.or.jp/top_runner/pdf/tr_electric_rice_cooker.pdf, ECCJ

Ministry of commerce, industry and energy (MOCIE), 2007. Regulation on Energy Efficiency Labeling and Standards, MOCIE's Notification 2007-70, Korea

Srinual Soksod and Panu Suwicharcherdchoo, 2006. "Rescaling the Energy Label No.5: version in Thailand", ENETT49-139-2, Energy for Sustainable Development, March 2006 